NASA Technical Memorandum 105249

AIAA-91-3440

\title{
Hydrogen/Oxygen Auxiliary Propulsion Technology
}

Brian D. Reed and Steven J. Schneider

Lewis Research Center

Cleveland, Ohio

Prepared for the

Conference on Advanced Space Exploration Initiative Technologies cosponsored by AIAA, NASA, and OAI

Cleveland, Ohio, September 4-6, 1991

\section{N/Sก}




\title{
HYDROGEN/OXYGEN AUXILIARY PROPULSION TECHNOLOGY
}

\author{
Brian D. Reed and Steven J. Schneider \\ National Aeronautics and Space Administration \\ Lewis Research Center \\ Cleveland, Ohio 44135
}

\begin{abstract}
$\underline{\text { Abstract }}$
This paper provides a survey of hydrogen-oxygen $(\mathrm{H} / \mathrm{O})$ auxiliary propulsion system (APS) concepts and low-thrust $\mathrm{H} / \mathrm{O}$ rocket technology. A review of $\mathrm{H} / \mathrm{O}$ APS studies performed for the Space Shuttle, Space Tug, Space Station Freedom, and Advanced Manned Launch System programs is given. The survey also includes a review of low-thrust $\mathrm{H} / \mathrm{O}$ rocket technology programs, covering liquid $\mathrm{H} / \mathrm{O}$ and gaseous $\mathrm{H} / \mathrm{O}$ thrusters, ranging from $6600 \mathrm{~N}(1500 \mathrm{lbf})$ to $440 \mathrm{mN}(0.1 \mathrm{lbf})$ thrust. Ignition concepts for $\mathrm{H} / \mathrm{O}$ thrusters and hightemperature, oxidation-resistant chamber materials are also reviewed.
\end{abstract}

\section{Introduction}

Auxiliary propulsion is required on every launch vehicle, satellite, and spacecraft. Examples of auxiliary propulsion include attitude control and orientation, stationkeeping, apogee insertion, rendezvous, docking, separation, midcourse correction, and planetary retro. Auxiliary propulsion maneuvers can range from millisecond pulse trains to long, steady-state burns. Depending on the application, thrust levels for auxiliary propulsion can range from $440 \mathrm{mN}(0.1 \mathrm{lbf})$ to $27 \mathrm{kN}$ $(6000 \mathrm{lbf})$. Thrusters in an auxiliary propulsion system (APS) are usually located throughout the vehicle, requiring a distribution network to supply propellants from the tanks. An APS must be able to provide frequent and rapid restarts, must have high cyclic life, and must have the flexibility to operate over a wide range of environmental conditions, often with long quiescent periods.

Currently, the primary candidate propellant combination for the APS of the space transfer vehicle (STV) is hydrogen-oxygen $(\mathrm{H} / \mathrm{O})^{1,2}$ These propellants are attractive because of their high performance and their nontoxic, noncorrosive nature and because of their compatiblity with other subsystems, including the main propulsion, power generation, and environmental control and life support systems. Integrating subsystems that use hydrogen, oxygen, and water could lead to a simpler and more operationally efficient vehicle.

In the past, the potential benefits of $\mathrm{H} / \mathrm{O}$ propellants have made them attractive candidates for APS's, including Space Shuttle and Space Station Freedom. However, they have yet to be implemented on an actual flight system due, primarily, to concerns about the feasibility of developing the technology to implement the concepts. Various APS concepts using liquid, gaseous, and supercritical H/O have been proposed over the years. Problems, though, are usually encountered in the design of various concepts, such as large volume and high-pressure storage requirements for gaseous $\mathrm{H} / \mathrm{O}$, long-term cryogenic storage and distribution, complexity and performance losses of propellant conditioning equipment, and uncertainties about thruster technology.

The primary propellant choice of APS's has been monopropellant hydrazine or the bipropellant combination of monomethylhydrazine (MMH) and nitrogen tetroxide (NTO). These Earth storable propellants have the advantages of a long, successful flight history, longterm storability with minimal thermal control, high bulk density, and either catalytic (monopropellant) or hypergolic (bipropellant) ignition. Earth storable propellants are also low performing compared with $\mathrm{H} / \mathrm{O}$, are highly toxic, and have limited capability for integration with other subsystems. The high reliability of Earth storable systems has outweighed the potential benefits of $\mathrm{H} / \mathrm{O}$, because of the uncertainties associated with $\mathrm{H} / \mathrm{O}$ systems. However, the need for high performance in STV missions and an increased awareness of the importance of efficient servicing, checkout, and maintenance, have called attention to H/O APS.

This paper surveys H/O APS concepts and the H/O thruster technology required to enable them. Included in this review are concepts and technologies generated from H/O development programs for the Space Shuttle, the proposed Space Tug, Space Station Freedom, and proposed advanced manned Earth-to-orbit vehicles. A matrix matching references with H/O APS concepts is 
given in Table I. A matrix of references and subjects in $\mathrm{H} / \mathrm{O}$ thruster technology is given in Table II.

TABLE I.-REFERENCES FOR H/O APS CONCEPTS

\begin{tabular}{|c|c|c|c|c|c|c|}
\hline $\begin{array}{l}\text { Refer- } \\
\text { ence }\end{array}$ & $\begin{array}{c}\text { Liquid } \\
\text { storage } \\
\text { and feed }\end{array}$ & $\begin{array}{l}\text { Liquid stor- } \\
\text { age and gas- } \\
\text { eous feed }\end{array}$ & $\begin{array}{c}\text { Gasous } \\
\text { storage } \\
\text { and feed }\end{array}$ & $\begin{array}{c}\text { Super-critical } \\
\text { storage and } \\
\text { feed }\end{array}$ & $\begin{array}{l}\text { Water } \\
\text { electro- } \\
\text { lysis }\end{array}$ & Application \\
\hline $\begin{array}{r}3 \\
4 \\
5 \\
7 \\
8 \\
9 \\
10 \\
12 \\
13 \\
15 \\
17 \\
32 \\
33 \\
34\end{array}$ & $\mathbf{X}$ & $\begin{array}{l}\mathbf{X} \\
\mathbf{X} \\
\mathbf{X} \\
\mathbf{X} \\
\mathbf{X}\end{array}$ & $\begin{array}{l}\mathrm{X} \\
\mathrm{X} \\
\\
\mathrm{X} \\
\mathrm{X} \\
\mathrm{X} \\
\mathrm{X}\end{array}$ & 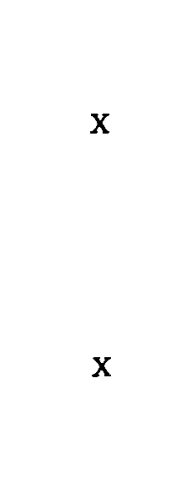 & $\begin{array}{l}\mathbf{X} \\
\mathbf{X} \\
\mathbf{X} \\
\mathbf{X} \\
\mathbf{X} \\
\mathbf{X}\end{array}$ & $\begin{array}{l}\text { Shuttle } \\
\text { Shuttle } \\
\text { Shuttle } \\
\text { Shuttle } \\
\text { Shuttle } \\
\text { Shuttle } \\
\text { Space Tug } \\
\text { Space Station } \\
\text { Space Station } \\
\text { Space Station } \\
\text { AMLS } \\
\text { Satellite } \\
\text { Satellite }\end{array}$ \\
\hline
\end{tabular}

TABLE II.-REFERENCES FOR H/O THRUSTER TECHNOLGY

(a) Thruster

\begin{tabular}{|c|c|c|c|c|c|}
\hline \multirow{2}{*}{$\begin{array}{c}\text { Refer- } \\
\text { ence }\end{array}$} & \multicolumn{2}{|c|}{ Liquid hydrogen/oxygen } & \multicolumn{3}{|c|}{ Gaseous hydrogen/oxygen } \\
\hline & $\begin{array}{c}5500 \mathrm{~N} \\
(1250 \mathrm{lbf})\end{array}$ & $\begin{array}{l}110 \mathrm{~N} \\
(25 \mathrm{lbf})\end{array}$ & $\begin{array}{c}5500 \mathrm{~N} \\
(1500 \mathrm{lbf})\end{array}$ & $\begin{array}{l}110 \mathrm{~N} \\
(25 \mathrm{lbf})\end{array}$ & $\begin{array}{r}<22 \mathrm{~N} \\
(5 \mathrm{lbf})\end{array}$ \\
\hline $\begin{array}{r}3 \\
6 \\
11 \\
18 \\
19 \\
20 \\
21 \\
22 \\
23 \\
24 \\
25 \\
26 \\
27 \\
28 \\
29 \\
30 \\
32 \\
33 \\
34 \\
35 \\
36\end{array}$ & $\begin{array}{l}\mathbf{X} \\
\mathbf{X}\end{array}$ & $\mathbf{X}$ & $\begin{array}{l}\mathbf{X} \\
\\
\mathbf{X} \\
\mathbf{X} \\
\mathbf{X} \\
\mathbf{X} \\
\mathbf{X} \\
\mathbf{X}\end{array}$ & $\begin{array}{l}\mathbf{X} \\
\mathbf{X} \\
\mathbf{X} \\
\mathbf{X} \\
\mathbf{X} \\
\mathbf{X}\end{array}$ & $\begin{array}{l}\mathbf{X} \\
\mathbf{X} \\
\mathrm{X} \\
\mathrm{X} \\
\mathrm{X}\end{array}$ \\
\hline
\end{tabular}


TABLE II.-CONCLUDED.

(b) Ignition concepts and chamber materials

\begin{tabular}{|c|c|c|c|c|c|c|c|}
\hline $\begin{array}{c}\text { Refer- } \\
\text { ence }\end{array}$ & $\begin{array}{l}\text { Spark } \\
\text { torch }\end{array}$ & $\begin{array}{l}\text { Integral } \\
\text { exciter and } \\
\text { igniter }\end{array}$ & $\begin{array}{c}\text { Plasma } \\
\text { torch }\end{array}$ & $\begin{array}{l}\text { Direct } \\
\text { spark }\end{array}$ & Catalytic & Resonance & $\begin{array}{c}\text { High- } \\
\text { temperature } \\
\text { chamber mate- } \\
\text { rials }\end{array}$ \\
\hline $\begin{array}{r}3 \\
6 \\
11 \\
18 \\
19 \\
23 \\
25 \\
26 \\
27 \\
29 \\
30 \\
32 \\
37 \\
38 \\
39 \\
40 \\
41 \\
42 \\
43 \\
44 \\
45 \\
46 \\
47 \\
48 \\
49 \\
50 \\
51 \\
52\end{array}$ & $\begin{array}{l}\mathbf{X} \\
\mathbf{X} \\
\mathbf{X} \\
\mathbf{X} \\
\mathbf{X} \\
\mathbf{X} \\
\mathbf{X} \\
\mathbf{X} \\
\\
\mathbf{X} \\
\mathbf{X} \\
\mathbf{X}\end{array}$ & $\begin{array}{l}\mathbf{X} \\
\mathbf{X} \\
\mathbf{X} \\
\mathbf{X} \\
\mathbf{X}\end{array}$ & $\mathbf{X}$ & $\mathrm{X}$ & $\begin{array}{l}\mathbf{X} \\
\mathbf{X} \\
\mathbf{X} \\
\mathbf{X}\end{array}$ & $\begin{array}{l}\mathbf{X} \\
\mathbf{X} \\
\mathbf{X} \\
\mathbf{X}\end{array}$ & $\begin{array}{l}X \\
X \\
X \\
X \\
X \\
X \\
X\end{array}$ \\
\hline
\end{tabular}

\section{Hydrogen-Oxygen Auxiliary Propulsion System Concepts}

\section{Space Shuttle}

There was an extensive program ${ }^{3,4}$ in the late 1960 's and early 1970's to develop H/O APS for the Space Shuttle. At the time, the Shuttle was envisioned to be a larger vehicle than the current version. The main propulsion tankage was internal to the orbiter vehicle. The orbiter and the booster were to be flyback and reusable. The Shuttle APS was to be composed of a liquid hydrogen and liquid oxygen orbital maneuvering system (OMS) for the orbiter and an $\mathrm{H} / \mathrm{O}$ attitude control system (later called the reaction control system (RCS)) for the orbiter and booster vehicles.

A cryogenic H/O RCS was considered, but there were concerns about excessive heat leaks into the cryogenic distribution system causing two-phase (and therefore uncontrollable) flow to the thrusters. ${ }^{4}$ A cryogenic distribution system (see Fig. 1) using expansion bellows accumulators and vacuum jacketed lines was proposed. ${ }^{5}$ The pumps in this system would be located near the storage tanks to avoid problems with cavitation caused by pressure drop and vaporization in the lines. Vacuum jacketed insulated lines would offer dual containment of propellants. The expansion bellows accumulators would accommodate the expansion of propellant due to heat soak. Recirculation fans in the distribution manifold would prevent localized hot spots from vaporizing the propellant. It was calculated ${ }^{5}$ that the oxygen manifold could accept $67.4 \mathrm{~kJ} / \mathrm{kg}(29 \mathrm{Btu} / \mathrm{lb})$ of heat before boiling of the propellant begins, while the hydrogen manifold could accept $36.3 \mathrm{~kJ} / \mathrm{kg}$ (156 Btu/lb) of heat. This would allow for a seven-day Shuttle mission with little or no boiloff in the distribution manifold.

Pulsing of cryogenic propellants was also a technology concern for a liquid H/O RCS. ${ }^{4}$ Heat soakback into the injector manifold and feed system could lead to twophase propellant flows. There were also concerns about 
reliable low-temperature ignition. However, operation of liquid $\mathrm{H} / \mathrm{O}$ thrusters in the pulse mode was demonstrated, ${ }^{6}$ with successful ignition of liquid hydrogen and oxygen (as well as gaseous and two-phase) propellants with minimal amount of soakback to the feed system. Demonstration of pulsing liquid $\mathrm{H} / \mathrm{O}$ thrusters, however, came too late to impact the Shuttle APS program.

The primary candidates for Shuttle RCS were systems with liquid storage and gaseous feed of propellants. ${ }^{3,7}$ After a preliminary screening, two gaseous feed RCS concepts ${ }^{3}$ (one using high-chamber-pressure engines, the other using low-chamber-pressure engines) were examined in detail by McDonnell Douglas Astronautics Corp. and TRW Systems Group, Inc.

In the high-chamber-pressure RCS concepts, ${ }^{3,4,8}$ the propellants would be stored as liquids in low-pressure, insulated tanks. Turbopumps, driven by gas generators, would be used to raise propellant pressures. Heat exchangers, also driven by gas generators, would condition the propellant. Different configurations using the gas generators in series and in parallel with the turbopumps and heat exchangers were investigated, as was the use of multiple gas generators. The propellants would be stored in gaseous accumulators, to be fed to the thrusters at a regulated pressure. The accumulators would also supply propellants to the gas generators. Thrusters would operate at 2.07 to $3.45 \mathrm{MPa}$ (300 to 500 psia) chamber pressure, with thrust levels ranging from 5120 to $8200 \mathrm{~N}$ (1150 to $1850 \mathrm{lbf}$ ) in the different designs. High cycle life of the heat exchangers and turbopump shaft accelerations on the order of 165000 to $200000 \mathrm{rpm} / \mathrm{sec}$ were identified as technology concerns. ${ }^{4}$ Furthermore, it was determined that 10 to 20 percent of the tanked propellant was required for propellant conditioning. ${ }^{7}$ An example of a high-pressure Shuttle RCS is shown in Fig. 2.

In the low-chamber-pressure $\mathrm{RCS},{ }^{3,9}$ the main propulsion tankage would supply gaseous propellants from boiloff. This propellant would be resupplied by propellant drawn from cryogenic storage and passed through a passive heat exchanger wrapped around the main propulsion tanks. The vapors from the tank would mix with liquid from the cryogenic tank in the feed system. The thrusters would operate at $4400 \mathrm{~N}$ (1000 lbf) and $104 \mathrm{kPa}$ (15 psia) chamber pressure. Because of the low chamber pressures, the thrusters would be limited to low area ratios $(5: 1),{ }^{7}$ reducing performance. A low-pressure Shuttle RCS in shown in Fig. 3.
An RCS using gaseous hydrogen and liquid oxygen feed was proposed as a possible compromise between the cryogenic and the liquid storage and gaseous feed systems. ${ }^{4}$ This concept eliminated the propellant conditioning equipment on the oxygen side, while avoiding the distribution of liquid hydrogen, which is a deep cryogen. Ignition requirements with gaseous hydrogen and liquid oxygen were thought to be similar to the Pratt \& Whitney RL-10 engine.

Vehicle studies concluded that a smaller orbiter vehicle with external, expendable main engine tankage would provide a more cost effective launch system. ${ }^{4}$ This resulted in a reduction in shuttle size along with a reduction in RCS impulse requirements. An analysis showed that the downsized vehicle did not have sufficient volume for the $\mathrm{H} / \mathrm{O} \mathrm{OMS}$, and development of $\mathrm{H} / \mathrm{O}$ technology was not considered justifiable without application to both OMS and RCS. A program decision was then made to design the APS for MMH and NTO propellants. The $\mathrm{H} / \mathrm{O}$ technology development continued in a limited fashion to provide a backup for the MMH-NTO system.

\section{Space Tug}

In the 1970's, the Space Tug vehicle was proposed to carry payloads from the Shuttle payload bay in low Earth orbit to high Earth orbit. One study ${ }^{10}$ by the Space Division of Rockwell International proposed an integrated liquid H/O APS for the Space Tug. Propellant would be drawn from the main propellant tanks into capillary reservoirs during main or auxiliary propulsion maneuvers. Positive displacement pumps would raise the propellant pressure from $140 \mathrm{kPa}$ (20 psia) to $1.62 \mathrm{MPa}$ (235 psia), with expansion bellows accumulators in the distribution manifold to feed the thrusters. The thrusters would operate at $110 \mathrm{~N}(25 \mathrm{lbf})$ and $1.03 \mathrm{MPa}$ (150 psia) chamber pressure and at a mixture ratio of 3 . A hydrogen bleed would actively cool the entire system to insure liquid from the tanks to the thruster inlet. A schematic of this APS concept is shown in Fig. 4.

The integrated liquid H/O APS was compared with a liquid $\mathrm{H} / \mathrm{O}$ system with dedicated storage tanks and with monopropellant hydrazine and MMH-NTO systems. The integrated $\mathrm{H} / \mathrm{O}$ concept was projected to have 5 percent better payload performance than the best dedicated cryogenic and storable concepts. The integrated $\mathrm{H} / \mathrm{O}$ APS had the advantage of providing a backup capability for the main propulsion system. Thruster performance and life, the functional and performance verification of 
the pump, zero-g reservoir, and thermodynamic control were the critical technology areas for the $\mathrm{H} / \mathrm{O}$ system. An $110 \mathrm{~N}$ (25 lbf), liquid $\mathrm{H} / \mathrm{O}$ thruster was later demonstrated. ${ }^{11}$

\section{Space Station Freedom}

In the mid to late 1980's, the baseline for Space Station Freedom propulsion ${ }^{12,13}$ consisted of an $110 \mathrm{~N}$ (25 lbf), gaseous $\mathrm{H} / \mathrm{O}$ system for high thrust maneuvers, such as reboost and collision avoidance and a waste gas resistojet system for low-thrust maneuvers, such as drag makeup. Gaseous H/O was to be supplied from highpressure water electrolysis and stored in $20.67 \mathrm{MPa}$ (3000 psia) tanks. The thruster would be fed from pressure regulators and operate at $8: 1$ mixture ratio (stoichiometric mixture). A schematic of the highpressure water electrolysis propulsion system is shown in Fig. 5.

There was an extensive effort to develop key technology for space station propulsion, including 110 to $220 \mathrm{~N}$ (25 to $50 \mathrm{lbf}$ ), gaseous $\mathrm{H} / \mathrm{O}$ thrusters. However, development of high-pressure water electrolysis and highpressure storage tanks were considered to be a high risk. This led to the baselining of a monopropellant hydrazine system for space station propulsion, ${ }^{14}$ with resistojets still used for low-thrust maneuvers.

A hybrid hydrazine and low-thrust $\mathrm{H} / \mathrm{O}$ system has been proposed ${ }^{15}$ for space station propulsion after the assembly phase. This concept would employ a lowpressure water electrolysis system and small, low-pressure gaseous accumulators to feed $440 \mathrm{mN}(0.1 \mathrm{lbf}) \mathrm{H} / \mathrm{O}$ thrusters. The $\mathrm{H} / \mathrm{O}$ system would perform 90 percent of the propulsion functions, greatly reducing hydrazine propellant resupply. The major technology concern associated with this concept is the developement of a long life, $\mathrm{H} / \mathrm{O}$ thruster.

\section{Advanced Manned Earth-to-Orbit Vehicles}

Studies began in the 1980's, to look at the next generation of manned launch systems, ${ }^{16}$ including the next generation of space shuttles, referred to both as the Shuttle II and as the Advanced Manned Launch System (AMLS), although AMLS studies include a family of vehicles. Shuttle II would be similar to the original Space Shuttle proposed in the late 1960's, with internal main propulsion tankage and a flyback booster. The Shuttle II would use an H/O OMS and RCS for operational efficiency and high performance.
A study of H/O APS concepts, performed ${ }^{17}$ by the Space Systems Division of Rockwell International, emphasized using operational efficiency as a design driver. The study was intended to be applicable to a range of manned spacecraft, but an AMLS Shuttle II vehicle was selected as representative. Twelve H/O RCS concepts falling into five general categories (gaseous storage and feed, liquid storage and feed, liquid storage and gaseous feed, liquid storage and supercritical feed, and supercritical storage and feed) were evaluated in terms of relative cost, ground servicing, and performance characteristics. The OMS was assumed to use liquid hydrogen and oxygen propellants. The technical risks associated with each RCS concept were also identified. From this initial screening, two H/O APS concepts (a gaseous storage and feed RCS and a liquid storage and feed RCS) were selected for detailed design, with the goal of minimizing the ground processing requirements. A pressurefed MMH-NTO APS was also designed, again, with reduction of processing as a driver.

In the gaseous $\mathrm{H} / \mathrm{O} \mathrm{RCS}$, the gaseous propellants would be drawn from the main propulsion system during ascent (gaseous hydrogen tapped from the main engine cooling jacket, gaseous oxygen heated by the main engine turbine exhaust) to fill the RCS tanks. To alleviate hydrogen storage requirements, the primary and vernier RCS thrusters would operate at a high mixture ratio (16:1). The OMS engines would use liquid hydorgen and oxygen, pressurized by gas from the RCS tanks. A schematic of this APS is shown in Fig. 6. The liquid $H / O$ RCS concept would store liquid hydrogen and oxygen in low-pressure, insulated tanks. Small recirculation pumps would be used in the RCS manifold to prevent localized vaporization of propellants. The OMS would employ pump-fed expander cycle engines. A schematic of the allliquid $\mathrm{H} / \mathrm{O}$ concept is shown in Fig. 7 .

The two selected H/O APS concepts were compared with the pressure-fed MMH-NTO APS concept in terms of APS processing time, mass properties, and life cycle costs. The gaseous H/O RCS concept, because of its relative simplicity, had the quickest APS processing time, while being competitive with the MMH-NTO APS in terms of life cycle costs and loaded APS mass. The all-liquid H/O APS had the highest life cycle costs (due to development costs for the OMS engine), but the lowest loaded APS mass.

The gaseous H/O RCS concept was estimated to have a turnaround processing time of 39 manhours, while the all-liquid $\mathrm{H} / \mathrm{O}$ concept was estimated to have 
98 manhours and the MMH-NTO concept, 355 manhours. By comparison, the cumulative turnaround processing time dedicated to servicing the current Space Shuttle APS is estimated to be $\mathbf{1 2 4 0}$ manhours. The gaseous $\mathrm{H} / \mathrm{O}$ and MMH-NTO RCS concepts were estimated to be close in life cycle costs $(\$ 421$ and $\$ 407$ million, respectively) and in loaded APS mass (16 030 and $15680 \mathrm{~kg}$ ( 35336 and $34561 \mathrm{lb}$ ), respectively). The all-liquid H/O APS was projected to have a life cycle cost of $\$ 732$ million. However, the all-liquid $\mathrm{H} / \mathrm{O}$ concept also offered a $3700-\mathrm{kg}(8100-\mathrm{lbm})$ mass saving over the MMH-NTO concept. This mass saving, which could be directly converted to payload, was not accounted for in life cycle costs.

All of the $\mathrm{H} / \mathrm{O}$ engines, including $220 \mathrm{~N}$ (50 lbf) class and $4000 \mathrm{~N}$ (900 lbf) class, gaseous $\mathrm{H} / \mathrm{O}$ thrusters, operating at high mixture ratios, were identified as technologies requiring development for the APS concepts. Cryogenic propellant acquisition, small electric cryogenic pumps, and vacuum jacketed lines represented key technologies for APS concepts using liquid hydrogen and oxygen. Finally, advanced health management was identified as crucial to increasing the operational efficiency of all APS concepts.

\section{Hydrogen-Oxygen Thruster Technology Liquid H/O Thrusters}

5500-N (1250-lbf) Class: One of the primary concerns of an all-liquid H/O APS for the Shuttle was operation of liquid $\mathrm{H} / \mathrm{O}$ thrusters in the pulse mode. ${ }^{4}$ Specifically, there were concerns about heat soakback into the injector manifold and feed system, leading to vaporization of propellants and uncontrollable propellant flows. Furthermore, there was the potential of the hydrogen freezing the oxygen and of the oxygen vaporizing the hydrogen in the injector manifold. There were also concerns about low-temperature ignition and combustion stability.

A technology program was conducted ${ }^{6,18}$ in the early 1970's by Aerojet Liquid Rocket Co. to address these issues. A thruster was to operate at $5500 \mathrm{~N}(1250 \mathrm{lbf})$ nominal thrust, 3.45 $\mathrm{MPa}$ (500 psia) chamber pressure, and 4:1 mixture ratio. The propellants were to enter the thruster at $4.31 \mathrm{MPa}$ (625 psia) pressure with hydrogen at $25 \mathrm{~K}\left(45^{\circ} \mathrm{R}\right)$ and oxygen at $83 \mathrm{~K}\left(150^{\circ} \mathrm{R}\right)$. Inlet temperatures were to range from 21 to $42 \mathrm{~K}$ (35 to $75^{\circ} \mathrm{R}$ ) for hydrogen and from 56 to $111 \mathrm{~K}$ (100 to $200^{\circ} \mathrm{R}$ ) for oxygen. After heat transfer analyses and subscale testing were performed, igniter and injector concepts were generated, leading to the design and successful firing of a thruster operating over a range of inlet conditions from cryogenic to ambient.

Analyses showed that the thermodynamic state of the propellants to the igniter assembly could not be guaranteed because of low flow rates and wide range of duty cycles. Thus a design that could ignite liquid, twophase, and gaseous hydrogen and oxygen was deemed necessary. A spark torch igniter concept was selected. In this ignition concept (shown in Fig. 8) a small portion of the hydrogen is injected into the igniter chamber, impinging on the spark-excited oxygen, and producing ignition at high mixture ratios (20 to 60 ). The remainder of the hydrogen is ducted down slotted passages in a chamber sleeve insert to provide cooling for the highmixture-ratio core flow. The core and coolant flows partially mix at the sleeve exit. The added hydrogen raises the gas temperature to 2200 to $3330 \mathrm{~K}$ (4000 to $6000^{\circ} \mathrm{R}$ ), providing a high-energy torch for thruster ignition. The unmixed hydrogen flows against the wall to provide film cooling. The torch-igniter design proved to be readily applicable to a wide range of propellant states, successfully igniting hydrogen and oxygen from cryogenic to ambient states in subscale igniter tests. Ignition was achieved in less than 20 msec at a spark energy level of $10 \mathrm{~mJ}$.

Two approaches to thermal management in the injector were evaluated. One was to use a prechilled manifold, where a low-velocity propellant recirculation loop would maintain the valve, injector manifolding, igniter, and propellants at the valve at cryogenic temperatures. This concept was rejected, however, when it was determined that the heat transferred back to the feed system by recirculation would be an order of magnitude higher than acceptable. The second approach was to use a low thermal capacity manifold. This approach (as shown in Fig. 9) used a thermal standoff between the valve and thruster to reduce heat leaks to the feed system and used low thermal capacitance metallic liners in a dual-walled, low-volume manifold to accelerate chilldown. Subscale testing demonstrated internal manifold wall chilldown times of $0.020 \mathrm{sec}$ and structurally safe manifold operation up to $6900 \mathrm{kPa}$ (1000 psia). Furthermore, the 24-element, like-on-like doublet injector was actively cooled by a portion of hydrogen through dump circuits in the injector face.

A series of 86 hot fire tests of the injector-igniter assembly was conducted at sea level, using a copper heat sink chamber with a 40:1 expansion area ratio. The vacuum specific impulse at nominal conditions was calculated to be $427 \mathrm{sec}$. The response time from 
electrical signal to 90 percent thrust was 75 msec. Pulse mode performance at impulse bits down to $889 \mathrm{~N} \cdot \mathrm{sec}$ (200 lbf-sec) was 90 percent of the steady-state value and was 75 percent of steady state down to $222 \mathrm{~N} \cdot \mathrm{sec}$ (50 lbf-sec) impulse. The thruster was found to have stable combustion with external excitation at a high frequency of $18000 \mathrm{~Hz}$ and was found to recover from 100 percent overpressure in $1.0 \mathrm{msec}$, when bombed with a 2-grain RDX (cyclotrimetylenetrinitramine) charge. Ten tests were conducted with a silicide-coated columbium chamber. On the final test the silicide coating eroded and burn through occurred, due to high temperature, injector-induced heat streaks.

In this same program, ${ }^{18}$ a gaseous-hydrogen-liquidoxygen thruster was tested. This thruster used the same igniter design and thermal management scheme as the liquid $\mathrm{H} / \mathrm{O}$ thruster. However, gaseous hydrogen was used to regeneratively cool the combustion chamber and film cool the nozzle. A series of 44 tests were conducted, delivering a specific impulse of $435 \mathrm{sec}$ at mixture ratio 4.5 and a chamber pressure of $3.45 \mathrm{MPa}$ (500 psia). Pulse mode performance was 93.4 percent of the steadystate value at an impulse bit of $245 \mathrm{~N} \cdot \mathrm{sec}(55 \mathrm{lbf} \cdot \mathrm{sec})$.

110-N(25-lbf) Class: In the late 1970's, an 110-N (25-lbf), liquid $\mathrm{H} / \mathrm{O}$ thruster was demonstrated ${ }^{11}$ by the Rocketdyne Division of Rockwell International. This program was conducted to provide the thruster technology for a liquid H/O APS on the Space Tug. ${ }^{10}$ The thruster was to operate at a nominal chamber pressure of $1.03 \mathrm{MPa}$ (150 psia) and mixture ratio 4 . The design hydrogen inlet temperature ranged from 22 to $33 \mathrm{~K}$ (40 to $60 \mathrm{R}$ ), while oxygen inlet temperatures varied from 89 to $122 \mathrm{~K}(160$ to $220 \mathrm{R})$.

After an evaluation of different injection systems, a dual sleeve, triaxial injection design was baselined. As shown in Fig. 10, the injection system used a primary combustor, where all of the oxygen and 8 percent of the hydrogen was introduced (50:1 mixture ratio); a secondary combustor, where 45 percent of the hydrogen was injected through an annulus (7.5:1 mixture ratio); and a boundary-layer coolant injector, where the remaining 47 percent of the hydrogen was introduced through an annulus for film cooling (4:1 mixture ratio). Radial injection of the secondary hydrogen was found to promote better mixing with the oxygen-rich flow from the primary combustor. Different boundary-layer coolant injection distances from the throat were evaluated, and $2.79 \mathrm{~cm}$ (1.10 in.) was eventually baselined.

A spark torch igniter was used for this thruster. Spark energy levels from 10 to $100 \mathrm{~mJ}$ were used. Although $10 \mathrm{~mJ}$ was determined to provide ignition, $25 \mathrm{~mJ}$ was selected as a safe nominal value. During pulse testing with very low temperature propellants, random nonignitions were experienced, even at $100 \mathrm{~mJ}$. The nonignitions may have been related to a short spark lead time and/or a faulty ignition cable. It was suggested, however, that another possible reason for the nonignitions was the need for a larger amount of energy to ionize cold liquid oxygen. Previous programs using the spark torch igniter concept did not attempt to thermally insulate the igniter manifold. This suggests that there was always some warming of propellant and that "cold" liquid oxygen was never actually seen at the spark gap. During the final phase of this testing, however, facility changes led to inlet propellants approaching a subcooled condition, perhaps colder than what had been seen before in a spark torch igniter. There was not time in the program, though, to conclusively determine the cause of the nonignitions.

The chamber was fabricated with a 50:1 area ratio, 100 percent bell nozzle from L-605 alloy. A disilicidecoated molybdenum chamber was selected as an alternative chamber material to allow increased wall temperatures up to $1370^{\circ} \mathrm{C}\left(2500^{\circ} \mathrm{F}\right)$ (by decreased film cooling) and corresponding performance increases.

Testing was performed at a simulated altitude of $30800 \mathrm{~m}$ (101 $000 \mathrm{ft})$. The majority of the testing was performed with L-605 chamber. A performance of $391 \mathrm{sec}$ specific impulse at a mixture ratio of $3.5: 1$ was achieved. A rise from 0 to 90 percent chamber pressure in $48 \mathrm{msec}$ was demonstrated. One $\mathrm{L}-605$ chamber failed when it was subjected to a high mixture ratio due to leaks in the facility hydrogen lines. The disilicide-coated molybdenum chamber was demonstrated briefly in pulse testing (no performance data were taken). 
Table III.-PERFORMANCE COMPARISON OF 6600-N (1500-lbf),

\section{GASEOUS H/O THRUSTERS}

[Chamber pressure, $2.07 \mathrm{MPa}$ (300 psia); mixture ratio, 4:1; area ratio, 40:1; ambient temperature propellants.

\begin{tabular}{|l|c|c|c|}
\hline \multicolumn{1}{|c|}{ Thruster assembly } & $\begin{array}{c}\text { Steady-state } \\
\text { specific impulse, } \\
\text { sec }\end{array}$ & $\begin{array}{c}\text { Minimum impulse bit } \\
\text { (MIB), } \\
\text { N-sec (lbf-sec) }\end{array}$ & $\begin{array}{c}\text { Specific impulse } \\
\text { at MIB, } \\
\text { sec }\end{array}$ \\
\hline $\begin{array}{l}\text { Coaxial injector - } \\
\text { regeneratively-cooled } \\
\text { chamber, dump-cooled } \\
\text { nozzle }\end{array}$ & 447 & $214(48)$ & 412 \\
$\begin{array}{l}\text { Premix injector- } \\
\text { regeneratively-cooled } \\
\text { chamber, film-cooled } \\
\text { throat }\end{array}$ & 444 & $222(50)$ & 350 \\
$\begin{array}{l}\text { Raised post triplet } \\
\text { injector - dump-cooled } \\
\text { chamber, film-cooled } \\
\text { throat }\end{array}$ & 432 & $147(33)$ & 390 \\
$\begin{array}{l}\text { Reverse flow thruster }\end{array}$ & 440 & $289(65)$ & \\
\hline
\end{tabular}

\section{Gaseous H/O Thrusters}

6800-N (1500-lbf) Class: The majority of gaseous $\mathrm{H} / \mathrm{O}$ thruster technology at the 6600-N (1500-lbf) thrust level was performed in the early to mid 1970's in a Shuttle APS technology program. An extensive review of this program is given in Ref. 19 . The program investigated different concepts for injectors, cooled thrust chambers, ignition systems, and valves for a thruster operating nominally at $6600 \mathrm{~N}(1500 \mathrm{lbf})$ thrust, $2.07 \mathrm{MPa}(300 \mathrm{psia})$ chamber pressure, and 4:1 mixture ratio.

Five injector concepts (as shown in Fig. 11) were investigated by various rocket manufacturers. The coaxial injector (Rocketdyne) ${ }^{20}$ contained 54 elements, each element with an oxidizer tube flush with the injector face and tapered $7^{\circ}$ at the outlet to enhance mixing between the oxygen and hydrogen. The premix triplet injector (Aerojet) ${ }^{21}$ contained 72 elements. In each element, the oxygen entered a "cup" region behind the injector face and was impinged upon by hydrogen streams from the side through I-shaped orifices. The raised post triplet injector (TRW) ${ }^{22}$ had three circular rings containing 144 oxidizer-fuel-oxidizer triplet elements. The trislot injector (Rocketdyne) ${ }^{20}$ consisted of 18 elements, in each of which hydrogen flow from two rectangular slots impinged upon oxygen flow from a central rectangular slot. In the reverse-flow injector (Bell Aerospace), ${ }^{23}$ hydrogen was injected in the reverse direction along the converging portion of the nozzle, thereby film cooling the spherical chamber. Oxygen was injected from the head end through a vortex cup, which caused the oxygen to spray radially outward and impinge the fuel coming off the chamber walls.

Acceptable combustion efficiency (94 to 98 percent) and stable combustion were obtained in all the injector types during screening tests with heat sink chambers. The coaxial and premix injectors demonstrated the best performance, durability, and heat transfer. The trislot injector, which performed poorly and caused heat streaks, was not investigated further.

Six thrust chamber cooling schemes were investigated using different combinations of regenerative, dump, and film cooling in the chamber, throat, and nozzle regions (Fig. 12). Dump cooling is similar to regenerative cooling in that fuel flows through channels or doubled walls in the thruster. The difference is that the flow exits along the wall for film cooling instead of into the injector manifold.

Four of these cooling schemes were used with the remaining four injectors in full thruster assembly tests conducted at altitude conditions over $\mathrm{z}$ range of chamber 
pressures, mixture ratios, and inlet conditions. All of the thrusters were tested with 40:1 area ratio nozzles. Spark type igniters were used in all four thruster assembly tests, even though one thruster also used a catalytic igniter. Various ignition concepts will be discussed in a. later section.

The coaxial injector was used with a regeneratively cooled chamber and dump cooled nozzle and a spark torch igniter. The premix triplet injector used a regeneratively cooled chamber and film-cooled throat and a spark torch igniter. The raised post triplet injector used a dump cooled chamber and film-cooled throat and spark plug and catalytic ignition systems. The reverse flow chamber assembly used a surface spark plug. A comparison of performance at nominal conditions is given in Table III. Steady-state performance varied from $\mathbf{4 3 2}$ to 447 sec of specific impulse for the four thruster assemblies.

A flight-weight engine was tested in a follow-on program conducted ${ }^{24}$ to characterize life and performance. A premix triplet injector was used with a regeneratively cooled chamber, film-cooled throat, 40:1 area ratio nozzle, and a spark-torch igniter. The thruster was tested at the same nominal conditions as the previous program (listed in Table III), accumulating over $6678 \mathrm{sec}$ of total firing time. Pulse durations of $100 \mathrm{msec}$ at a frequency of $2 \mathrm{~Hz}$ were performed, accumulating 51000 pulses. Characteristic exhaust velocity efficiencies of 93 percent were achieved throughout the testing.

110-N (25-lbf) Class: Technology programs for Space Station Freedom propulsion make up the majority of the work on gaseous $\mathrm{H} / \mathrm{O}$ thrusters at the 110 to $220 \mathrm{~N}$ (25 to $50 \mathrm{lbf}$ ) thrust level and represent the most recent work performed in low-thrust $\mathrm{H} / \mathrm{O}$ propulsion. Three different thruster designs were developed, and boilerplate versions were tested under altitude conditions. ${ }^{13}$ Space Station thrusters were to be operated to $4: 1$ mixture ratio for optimum performance. Later, the design point was changed to 8:1 mixture ratio to interface with a water-electrolysis-based propulsion system. Both steadystate and pulse firings were required with a thruster life of $8900 \mathrm{kN} \cdot \mathrm{sec}$ ( 2 million lbf $\cdot \mathrm{sec}$ ) and a performance of $345 \mathrm{sec}$.

Bell Aerospace ${ }^{25}$ scaled down their 6600-N (1500-lbf) reverse flow thruster to $220 \mathrm{~N}$ (50 lbf) with a $517-\mathrm{kPa}$ (75-psia) chamber pressure and mixture ratio of 4:1. Increased heating of the chamber resulted from the scaledown, prompting changes to the oxygen centerflow orifice in the vortex cup. At its design point, the reverse-flow thruster achieved a specific impulse of $397 \mathrm{sec}$. When the water electrolysis propulsion system was baselined for the space station, requiring 8:1 mixture ratio operation, a new thruster was fabricated (although the 40:1 area ratio, 80 percent bell nozzle from the previous testing was retained). For cooling purposes, it was desirable to keep the fuel flow rate in the nozzle constant. In order to increase the oxygen flow rate, then, chamber pressure and thrust were allowed to increase to $662 \mathrm{kPa}$ (96 psia) and $320 \mathrm{~N}$ (75 lbf), respectively. Ten 300 -sec tests were conducted at the new design point, achieving specific impulse values up to $347 \mathrm{sec}$. Then the thruster was fired over a mixture range of 3 to 8 . In total, $5282 \mathrm{sec}$ of firing time, and over $1479 \mathrm{kN} \cdot \mathrm{sec}$ (330 $000 \mathrm{lbf} \cdot \mathrm{sec}$ ) of impulse were accumulated, without any serious degradation of the hardware.

Aerojet ${ }^{25,26,27}$ used the spark torch igniter as the basis for their 110-N (25-lbf) thrusters. As in the torch igniters, a high mixture ratio core flow is generated by radial injection of oxygen and a small portion of hydrogen. The remaining hydrogen is ducted through slotted passages in a chamber sleeve insert for film cooling. At the sleeve exit, the coolant flow partially mixes with the core flow, lowering the overall mixture ratio. The amount of fuel film cooling is changed by using different flow splitting washers in the hydrogen manifold. The regeneratively cooled thrusters used the high-efficiency, high-heat-flux platelet stack injectors. The first thruster built was designed for a 4:1 mixture ratio and 524-kPa (75-psia) chamber pressure and had a 113:1 area ratio nozzle. At mixture ratio 4, the specific impulse varied from $423 \mathrm{sec}$ with 59 percent fuel film cooling to 340 sec with 92 percent fuel film cooling. The thruster, tested at mixture ratios from 2 to 8 accumulated $22402 \mathrm{sec}$ of test time and over $2395 \mathrm{kN} \cdot \mathrm{sec}$ (538 $000 \mathrm{lbf} \cdot \mathrm{sec}$ ) of total impulse. There was no degradation of the thruster at the end of testing.

To accommodate the change in space station propulsion requirements, a second thruster was built ${ }^{27}$ with an 8:1 mixture ratio design point and a 33:1 area ratio nozzle. A schematic of this thruster is shown in Fig. 13. At a mixture ratio of 8 and 61 percent fuel film cooling, a specific impulse of $341 \mathrm{sec}$ was achieved. Specific impulse went to $360 \mathrm{sec}$ at 49 percent fuel film cooling and down to $325 \mathrm{sec}$ at 69 percent fuel film cooling. The thruster has accumulated over $10370 \mathrm{sec}$ of firing time and over $1153 \mathrm{kN} \cdot \sec (259200 \mathrm{lbf} \cdot \mathrm{sec})$ of total impulse with no degradation of the hardware. Testing of this thruster is continuing in support of a low-thrust rocket flow field modeling program. ${ }^{28}$ 
Rocketdyne ${ }^{29,30}$ fabricated seven injectors and six regeneratively cooled, 30:1-area-ratio nozzles for space station propulsion. A schematic of the Rocketdyne thruster is shown in Fig. 14. The Rocketdyne design uses an injector with a central annulus for sparkenergized oxygen, 12 impinging hydrogen elements, 12 coaxial elements, and 12 film-cooling elements along the outer edge. The later versions of the injector have a modified oxidizer post arrangement to reduce the heat flux, providing cooler chamber wall temperatures. The first (prototype) Rocketdyne thruster used 40 percent film cooling and contained wires in the cooling channels. The prototype thruster was fired for over 10400 pulses and accumulated over $87 \mathbf{4 0 0} \mathrm{sec}$ of test time. A thruster assembly using 15 percent film cooling has, at mixture ratio 8 , achieved 355 sec specific impulse. The thruster has accumulated over $43000 \mathrm{sec}$ of test time and over $4788 \mathrm{kN} \cdot \mathrm{sec}(1076500 \mathrm{lbf} \cdot \mathrm{sec})$ of total impulse. Testing of the thruster is continuing in support of a program applying Rayleigh scattering diagnostics to rocket plumes. ${ }^{31}$

22-N (5 lbf) Class and Below: In the mid 1960's, a 4.4-N (1-lbf) thruster was developed and tested ${ }^{32}$ as part of a water electrolysis reaction control system for spacecraft. The thruster received propellants from a tank containing a stoichiometric mixture of gaseous hydrogen and gaseous oxygen. A schematic of the thruster assembly is in Fig. 15. The final form of the injector (Form $\mathrm{C}$ in Fig. 15) consisted of two, 0.16-cm (0.063-in.) sintered disks, welded in series to a housing or union. The injector design was intended to provide uniform flow into the chamber. The gaseous $\mathrm{H} / \mathrm{O}$ mixture was ignited by a miniature spark plug in the combustor wall. The injector union was mounted to a nickel chamber with a 35.4:1-expansion-ratio, 80-percent bell nozzle.

The thruster was tested in vacuum pressures down to 0.5 torr (0.01 psia) or $33220 \mathrm{~m}$ (109000 ft) altitude. At its design chamber pressure of $103 \mathrm{kPa}$ (15 psia), specific impulse was $338 \mathrm{sec}$. At a chamber pressure of $79 \mathrm{kPa}$ (11.5 psia), thrust was $4.4 \mathrm{~N}$ (1 lbf), and specific impulse was 328 sec. When chamber pressure dropped to $10.3 \mathrm{kPa}$ (1.5 psia), thrust decayed to $440 \mathrm{mN}$ (0.1 lbf), and specific impulse was $143 \mathrm{sec}$ Erratic ignitions occurred below the $27.6-\mathrm{kPa}$ (4-psia) chamber pressure level, and no ignitions were possible below $6.9 \mathrm{kPa}$ (1 psia). One hundred steady-state tests were performed, generally 3 to $5 \mathrm{sec}$ in duration. Forty-three pulse tests were performed with pulse on times ranging from 10 to $500 \mathrm{msec}$ and off times from 100 to $5000 \mathrm{msec}$ (10 percent duty cycle), with tests consisting of 10 to 100 pulses. No erosion of the radiation-cooled nickel thruster occurred despite operating at stoichiometric mixture ratio.

In the early 1970's, the Marquardt Co. developed and tested both boilerplate ${ }^{33}$ and flight-weight ${ }^{34}$ versions of $22 \mathrm{~N}(5 \mathrm{lbf})$ and $440 \mathrm{mN}(0.1 \mathrm{lbf})$ thrusters as part of a program to develop a water electrolysis propulsion system for satellites. All of the thrusters operated at a stoichiometric mixture ratio and were tested in vacuum

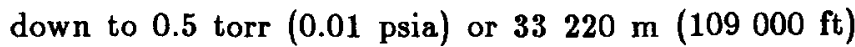
altitude.

The 22-N (5-lbf) thruster had a nominal chamber pressure of $345 \mathrm{kPa}$ (50 psia), with throttling to $6.7-\mathrm{N}$ (1.5-lbf) thrust and 103-kPa (15-psia) chamber pressure. The injector consisted of six premix coaxial elements surrounded by $\mathbf{2 4}$ hydrogen film-cooling holes. Each premix coaxial element consisted of an oxygen orifice surrounded by three hydrogen orifices, with a plate forcing the hydrogen flow to turn a $90^{\circ}$ angle into the oxygen stream. Sixty percent fuel film cooling was used in the radiation-cooled chamber. A spark plug in the center of the injector face was used as the ignition source. The chamber material was disilicide-coated molybdenum and a 40:1-area-ratio, 80-percent bell nozzle was used. Two boilerplate and two flight-weight versions of the thruster were tested.

The final flight-weight version of the thruster gave a specific impulse of $355 \mathrm{sec}$ at $22-\mathrm{N}$ (5-lbf) thrust. The maximum chamber temperature attained was $1370^{\circ} \mathrm{C}$ $\left(2500^{\circ} \mathrm{F}\right)$. A total of 152015 firings were accumulated in a combination of steady-state and pulse testing, resulting in a total firing time of $4.16 \mathrm{hr}$. The maximum duration run was $3600 \mathrm{sec}$, while a majority of firings were made in 50- and 100-msec pulses at frequencies of 1 to $5 \mathrm{~Hz}$. There was no serious degradation of the chamber or injector at the end of testing.

The 440-mN (0.1-lbf) thruster was designed for a nominal chamber pressure of $517 \mathrm{kPa}$ (75 psia), with throttling to $135 \mathrm{mN}(0.03 \mathrm{lbf})$ thrust at $172 \mathrm{kPa}$ (25 psia) chamber pressure. A single element, premix coaxial injector was used, similar to the injector elements used on the 22-N (5-lbf) thruster. A spark plug, radially mounted between the injector and chamber was used as the ignition source. Thick-walled chambers with an 100:1 area ratio, conical nozzle were used. A schematic of the final flight-weight design is shown in Fig. 16.

At $476 \mathrm{kPa}$ (69 psia) chamber pressure, the specific impulse was calculated (from JANNAF methodology, since thrust was not measured) to be $331 \mathrm{sec}$, and the 
thrust, $440 \mathrm{mN}(0.1 \mathrm{lbf})$. At $193 \mathrm{kPa}(28 \mathrm{psia})$ chamber pressure, the specific impulse was calculated to be $298 \mathrm{sec}$, and the thrust to be $180 \mathrm{mN}(0.04 \mathrm{lbf})$. The maximum combustion chamber temperature was $970{ }^{\circ} \mathrm{C}$ $\left(1780^{\circ} \mathrm{F}\right)$. Both steady-state and pulse testing were performed, the longest run lasting $1800 \mathrm{sec}$ and with pulses down to $100 \mathrm{msec}$ on, $100 \mathrm{msec}$ off.

One disilicide-coated molybdenum chamber and a disilicide-coated columbium chamber were tested with the final flight-weight injectors. The molybdenum chamber accumulated 100070 firings and $3.52 \mathrm{hr}$ of total firing time before it failed due to erosion of the coating. The columbium chamber achieved 301726 firings and $10.07 \mathrm{hr}$ of firing time (meeting the program goal) before it also failed due to erosion of the coating. In both cases, the coating failures were attributed to a chemical reaction with glowing particles that were eroding away from the spark plug tip. A high spark energy of $10 \mathrm{~mJ}$ was used in the flight-weight testing which caused erosion of the spark plug. The higher spark energy was used to ignite at low supply pressures, however, there was no appreciable difference between the high and low spark energies in igniting at lower pressures.

In the early 1980's the Jet Propulsion Laboratory (JPL) conducted a program ${ }^{35,36}$ to evaluate rhenium metal for low-thrust, gaseous $\mathrm{H} / \mathrm{O}$ engines. Rhenium has a melting temperature of $3180^{\circ} \mathrm{C}\left(5760^{\circ} \mathrm{F}\right)$, but is very susceptible to oxidation. Therefore, a high amount of hydrogen film cooling was required to protect the chamber wall from oxidation products. The rhenium chambers were fabricated by chemical vapor deposition, which will be described in a later section.

A 2.2-N (0.5-lbf) rhenium thruster was fabricated and tested. ${ }^{35}$ The injector was a single coaxial element surrounding a central spark plug. The hydrogen was divided into two flows, 10 percent injected directly for ignition and primary combustion and 90 percent ducted through a slotted chamber sleeve insert for film cooling. A schematic of this thruster is shown in Fig. 17.

A total of $\mathbf{4 7}$ tests was conducted in a vacuum down to 1 torr $(0.02 \mathrm{psia})$ or $31820 \mathrm{~m}(104400 \mathrm{ft})$ simulated altitude. Over $1 \mathrm{hr}$ of test time was accumulated, with the longest run being $1800 \mathrm{sec}$. At a mixture ratio of 4:1 and a chamber pressure of $524 \mathrm{kPa}$ (76 psia), a specific impulse of $381 \mathrm{sec}$ was achieved. In order to increase performance, the hydrogen film cooling was reduced to 83 percent, and mixture ratio to 3.5:1. At the same chamber pressure, specific impulse went to $418 \mathrm{sec}$. The maximum throat temperature measured during the testing was $1740^{\circ} \mathrm{C}\left(3160{ }^{\circ} \mathrm{F}\right)$. No degradation or oxidation of the rhenium chamber was experienced during testing.

In another test program, ${ }^{36} \mathrm{JPL}$ compared the performance of a 12-N (2.7-lbf) rhenium thruster with a copper alloy, regeneratively cooled thruster. The thrusters operated at $207-\mathrm{kPa}$ (30-psia) chamber pressure and 2.5:1 mixture ratio, although they were originally designed and fabricated for a 3.45-MPa (500-psia) chamber pressure. Each thruster used a platelet stack injector and spark ignition, similar to the Aerojet space station thruster injector-igniter. An 100:1-area-ratio, 80-percent bell nozzle was used with each thruster, while an $18^{\circ}$ half-angle, conical nozzle was used on a stainlesssteel thruster with a chamber design identical to the rhenium chamber. The stainless-steel thruster was used for checkout of hardware and for comparison of nozzle contours.

The thrusters were tested at pressures down to 0.25 torr ( $0.005 \mathrm{psia})$ or $34630 \mathrm{~m}(113620 \mathrm{ft})$ simulated altitude. Eight tests were conducted with the regeneratively cooled thruster, at 86-percent fuel film cooling, giving a specific impulse of $369 \mathrm{sec}$ at 2.5:1 mixture ratio. Forty-one tests were conducted on the rhenium thruster, accumulating a total run time of $2852 \mathrm{sec}$. At 86-percent fuel film cooling, a specific impulse of $371 \mathrm{sec}$ was achieved at 2.5:1 mixture ratio. At 89-percent fuel film cooling and 2.5:1 mixture ratio, performance was lowered to $366 \mathrm{sec}$. The maximum temperature experienced by the rhenium chamber was $1848^{\circ} \mathrm{C}\left(3359^{\circ} \mathrm{F}\right)$. No degradation of the rhenium chamber occurred in testing.

Analyses had shown that the bell nozzle would produce $13 \mathrm{sec}$ more of specific impulse performance than the conical nozzle. However, testing showed that, at the same throat temperature and characteristic exhaust velocity, the conical nozzle produce 9 more seconds of specific impulse than the bell nozzle at 2.5 mixture ratio. This difference in performance decreased with increasing mixture ratio.

\section{Ignition Concepts}

One of the major differences between $\mathrm{H} / \mathrm{O}$ and Earth storable propellants is the need for an ignition system. An APS imposes on an ignition system the requirements of fast-response, high-cycle life, and the capability to operate over a wide range of conditions. Furthermore, since the number of thrusters in an APS is usually high (30 to 40 ), the power requirement and the number of any 
supporting systems for each ignition system must be kept to a minimum. There was a great deal of research into $\mathrm{H} / \mathrm{O}$ ignition during the Shuttle technology programs, and this will be the focus of this section. A comparison of these ignition systems for $6600-\mathrm{N}$ (1500-lbf), gaseous $\mathrm{H} / \mathrm{O}$ thrusters is given in Ref. 19. An extensive survey of ignition concepts for liquid-oxygen-hydrocarbon booster engines, some of which are applicable to $\mathrm{H} / \mathrm{O}$ thrusters, is given in Ref. 37 .

Spark ignition is the most developed and reliable ignition source for $\mathrm{H} / \mathrm{O}$ engines, with lifetimes of hundreds of thousands of cycles. As described earlier, use of a spark plug in a high mixture ratio flow to create a hot torch, has been proven to be an effective ignition source from cryogenic to ambient inlet conditions. However, the desire for a nonelectrical alternative to spark systems led to investigations of catalytic and resonance ignition. Catalytic and resonance ignition have been successfully demonstrated, but have not reached the stages of development of spark ignition systems.

The spark torch igniter concept (as shown in Fig. 8) has been shown to be a highly reliable and durable ignition source for $\mathrm{H} / \mathrm{O}$ thrusters. Aerojet ${ }^{38}$ used the igniter concept in their gaseous, 6600-N (1500-lbf) thruster, achieving ignition around 10-msec from electrical start, using $5 \mathrm{~mJ}$ of energy at $20000 \mathrm{~V}$. Rocketdyne ${ }^{39}$ built a flight-type exciter with an integral spark plug. This eliminated the need for a high-voltage, pressurized cable between the exciter unit and the spark plug. This igniter also differed from Aerojet's in that it discharged in a fuel and oxidizer mixture. A 10-msec fuel lead was used, ignition typically occurring $33 \mathrm{msec}$ from electrical start, using $22 \mathrm{~mJ}$ of energy per spark at $10000 \mathrm{~V}$.

Aerojet $^{38}$ also investigated a plasma torch ignition system as a low-power alternative to spark torch igniters. In this approach, a portion of the hydrogen was ionized by a pulsing electrical energy source of $0.2 \mathrm{~mJ}$ at $5000 \mathrm{~V}$. Oxygen was injected in an annulus around the plasma plug tip for ignition. The remaining hydrogen mixed with the igniter core flow downstream, providing a hot torch for main stage ignition. Ignition typically occurred in $10 \mathrm{msec}$ from electrical start and was reliable over a wide range of operating conditions.

Bell Aerospace ${ }^{23}$ used a spark plug mounted through the chamber wall of their reverse-flow thruster, for direct spark ignition of the fuel. A small amount of oxygen was injected on the upstream side of the spark plug to enhance ignition, though some wall erosion occurred if the quantity of oxygen was not tightly controlled. Ignition typically occurred within $10 \mathrm{msec}$ from electrical start. Direct spark ignition was reliable for the reverse flow thruster, but it may not be adaptable to other thruster types.

The use of noble metal catalysts to create spontaneous ignition of $\mathrm{H} / \mathrm{O}$ mixture in a single thermal bed reactor had been demonstrated in the 1960's. ${ }^{40,41}$ However, ignition response times varied drastically with propellant temperature and were no quicker than $200 \mathrm{msec}$. Means to improve the response time of catalytic igniters were investigated. A design by TRW ${ }^{42}$ (Fig. 18) used downstream injection of oxygen into the effluent from the catalytic reactor. This technique reduced the ignition response time of ambient temperature propellants to about 25 to $30 \mathrm{msec}$. With cryogenic temperature propellants, the response time was 40 to 50 msec. The life of two noble-metal-based catalysts Shell 405 and Engelhard MFSA - were evaluated. Steady-state firings up to $4000 \mathrm{sec}$ and pulse mode operation up to 5000 thermal cycles were achieved without significant physical or chemical degradation to the catalyst bed. The ultimate life of the bed, however, was not determined.

Resonance heating of gaseous hydrogen to ignite $\mathrm{H} / \mathrm{O}$ mixtures had been demonstrated in the 1960's. ${ }^{43,44}$ The concept of resonance heating is illustrated in Fig. 19. Hydrogen gas flows through a sonic nozzle and impinges on the resonance tube, a detached shock forming around the opening. At certain nozzle-tube spacings (corresponding to regions where stagnation pressure rises with increasing distance from the nozzle), the detached shock will oscillate in the tube at the natural frequency of the gases trapped in the tube, initiating a resonance condition. The periodic compression and expansion of the trapped gases produces intense noise and rapid temperature rise. As oxygen is injected for ignition, the combustion gases flow into the thruster to provide a hot torch for main stage ignition. Rocketdyne ${ }^{39}$ investigated resonance ignition for their 6600-N (1500-lbf) thruster. The ignition response from valve signal to 90 percent igniter pressure was 20 to $30 \mathrm{msec}$ when used on workhorse hardware and about $50 \mathrm{msec}$ for the thruster assembly.

JPL conducted a program ${ }^{45}$ to determine the minimum spark energy for very low thrust, gaseous $\mathrm{H} / \mathrm{O}$ thrusters, in support of their 2.2-N (0.5-lbf) rhenium thruster. Spark energy was a concern for very low-thrust engines, since high energy spark discharge $(10 \mathrm{~mJ})$ was thought to be responsible for the failure of Marquardt's 
440-mN (0.1-lbf) thrusters. ${ }^{34}$ The JPL program determined that the minimum spark energy for reliable and repeatable ignition was $0.2 \mathrm{~mJ}$. An integral exciter-sparkplug ignition system was assembled and tested successfully on the 2.2-N (0.5-lbf) rhenium thruster.

\section{High-Temperature, Oxidation-Resistant Chamber Materials}

High-temperature, oxidation-resistant chamber materials $^{46}$ may offer radiation-cooled, $\mathrm{H} / \mathrm{O}$ thrusters unprecedented thermal margins, while inhibiting oxidation of the chamber wall. Performance increases could be obtained by significantly reducing the amount of film cooling, thus allowing running at higher temperatures. Alternatively, and perhaps more importantly, the thermal margin could be exploited by running at lower temperatures, significantly increasing thruster life. These materials may be the key technology for $\mathrm{H} / \mathrm{O}$ thrusters operating at high mixture ratios, very long life thrusters, or thrusters operating over a wide range of propellant states.

The most developed of the high-temperature, oxidation-resistant chamber materials is rhenium metal coated with iridium for oxidation protection. Iridiumcoated rhenium thrusters have been successfully fabricated by Ultramet ${ }^{47}$ using chemical vapor deposition (CVD). In CVD, a gaseous compound of the material is passed over a heated mandrel of the thruster contour, resulting in thermal decomposition of the gas and subsequent deposition of the material on the mandrel. After coating the mandrel to the desired thickness, the mandrel is chemically removed.

As described earlier, JPL has tested 2.2-N (0.5-lbf ${ }^{35}$ and $12-\mathrm{N}(2.7-\mathrm{lbf})^{36}$ uncoated rhenium chambers $\mathrm{H} / \mathrm{O}$ with propellants, at temperatures above $1700^{\circ} \mathrm{C}$ $\left(3100^{\circ} \mathrm{F}\right)$, using 83 to 90 percent fuel film cooling. Aerojet $^{46,48}$ has tested a $22-\mathrm{N}$ (5-lbf), iridium-coated rhenium thruster, operating on MMH-NTO propellants at $2200^{\circ} \mathrm{C}\left(4000^{\circ} \mathrm{F}\right)$ for $15 \mathrm{hr}$ without significant chamber degradation. There has also been testing of 66-N (15-lbf) and 440-N (100-lbf) iridium-coated rhenium thrusters on MMH-NTO. ${ }^{49,50}$ Iridium-coated rhenium thrusters have been proposed ${ }^{51}$ for the Space Shuttle vernier engines. Using the existing injectors, the iridiumcoated rhenium thrusters are projected to increase the life of vernier engines from 10 missions to 100 missions.

There are on-going investigations to apply protective oxide coatings on iridium-coated rhenium thrusters
(Ultramet of Pacoima, California under NASA contract NAS3-25648). There are also investigations to evaluate use of composites of graphite fibers and a mixed hafnium carbide and tantalum carbide matrix as chamber materials (Ceramic Composites, Inc., of Millersville, Maryland, under NASA contract NAS3-26243). This composite material offers a lightweight and higher temperature $\left(3980^{\circ} \mathrm{C}\left(7190^{\circ} \mathrm{F}\right)\right)$ alternative to iridium-coated rhenium. In Europe ${ }^{52}$ the lower-temperature silicon carbide matrix composite thrusters have been tested on MMH-NTO at $1600^{\circ} \mathrm{C}\left(2900^{\circ} \mathrm{F}\right)$, at 5-N (1.1-lbf) thrust for up to $50 \mathrm{hr}$ and at 2000-N (450-lbf) thrust for $1000 \mathrm{sec}$.

\section{Hydrogen-Oxygen Component Technology}

There are other key system technologies needed for the various H/O APS concepts described earlier that are not covered in this survey. These include valves, both for the thrusters (which were investigated in many of the thruster technology programs) and for the system itself. In particular, small, fast-acting, long-life valves operating with cryogenic propellants are a key. Insulated tanks that can maintain cryogenic propellants, particularly the low-temperature hydrogen, for time periods of months are critical for APS concepts storing liquid hydrogen and oxygen and, of course, the main propulsion system. The technology area of zero-g liquid hydrogen and oxygen propellant acquisition and gauging is important to both main and auxiliary propulsion systems. Liquid hydrogen and oxygen distribution system may require the development of small vacuum jacketed lines. Lightweight, highpressure tanks would be important in reducing the mass in systems storing gaseous hydrogen and oxygen at high pressure. High-pressure and recirculation pumps that can be driven by electric motors at relatively low power levels are important in avoiding complex gas generator and turbopump assemblies. Some APS concepts require the development of expansion bellows accumulators that can undergo hundreds of cycles without plastic deformation. Important to any APS, regardless of propellant, is a level of vehicle health management that allows for automated checkout and calibration, detection of propellant leakage and imminent component failures, and failure management. The nature of a health management system is dependent on the type of propellant used and, with $\mathrm{H} / \mathrm{O}$, the states of propellant used.

\section{$\underline{\text { Summary }}$}

A survey of $\mathrm{H} / \mathrm{O}$ APS concepts and low-thrust $\mathrm{H} / \mathrm{O}$ rocket technology has been given. $\mathrm{H} / \mathrm{O}$ propellants are attractive because of their high performance, their 
nontoxic, noncorrosive nature, and their compatibility with other subsystems. Studies of H/O APS's have shown advantages in performance and operational efficiency over storable designs. Historically, however, concerns about the feasibility of H/O APS concepts and/or the immaturity of the $\mathrm{H} / \mathrm{O}$ technology have led to the selection of storable APS's. If a H/O APS is to be implemented on STV and other future spacecraft, $\mathrm{H} / \mathrm{O}$ propulsion technology requires further maturation. As shown in this survey, much of the foundation for development of $\mathrm{H} / \mathrm{O}$ APS and low-thrust $\mathrm{H} / \mathrm{O}$ rocket technology has been laid.

\section{$\underline{\text { References }}$}

1. Space Transfer Vehicle Concepts and Requirements Study. Martin Marietta, NASA Contract NAS8-36856.

2. Space Transfer Vehicle Concepts and Requirements Study. Boeing Aerospace, NASA Contract NAS8-36857.

3. Proceedings, Space Transportation System Propulsion Technology, Vol. II, Auxiliary Propulsion System. NASA TM X-67246, 1971.

4. Kelly, P.J., and Schweickert, T.F., "Space Shuttle Auxiliary Propulsion System Design Study, Executive Summary," MDC-E0674, McDonnell Douglas Corp., NASA CR-128818, Dec. 1972.

5. Akkerman, J.W., "Shuttle Reaction Control System, Cryogenic Liquid Distribution System Study," NASA TM X-68913, 1972.

6. Herr, P.N. and Schoenman, L., "Demonstration of a Pulsing Liquid Hydrogen/Oxygen Thruster," NASA TM X-71444, 1973.

7. Pohl, H.O., Vaughan, C.A., and Kendrick, D., "Space Shuttle Reaction Control System," SAE Paper 700802, Oct. 1970.

8. "Space Shuttle High Pressure Auxiliary Propulsion Subsystem Definition," NASA CR-115161, 1971.

9. Kelly, P.J. and Schweickert, T.F., "Space Shuttle Low Pressure Auxiliary Propulsion Subsystem Definition, " MCD-E0293, McDonnell Douglas Corp. NASA CR-114945, Jan. 1971.
10. Nichols, J.F., "Study of Liquid Oxygen/Liquid Hydrogen Auxiliary Propulsion Systems for the Space Tug," SD75-SA-0043, Rockwell International Corp., NASA CR-134790, June 1975.

11. Eberle, E.E. and Kusak, L., "Liquid Oxygen/Liquid Hydrogen Auxiliary Propulsion System Thruster Investigation," RI/RD79-217, Rockwell International Corp., NASA CR-159674, Dec. 1979.

12. Donovan, R.M., Sovey, J.S., and Hannum, N.P.: Space Station Propulsion Analysis Study. AIAA Paper 84-1326, June 1984, (Also, NASA TM-83715).

13. Jones, R.E., et al., "Space Station Propulsion System Technology," NASA TM-100108, 1987.

14. Morano, J.S. and Delventhal, R.A., "Design and Operation of the US Space Station Freedom Propulsion System," AIAA Paper 91-1929, June 1991.

15. Zimmermann, F.S. and France, C., "A Hybrid High Thrust Hydrazine/Low Thrust Hydrogen-Oxygen Propulsion Option for Space Station Freedom," AIAA Paper 91-1834, June 1991.

16. Talay, T.A., "Shuttle II," SAE Paper 871335, 1987.

17. Gerhardt, D.L., "Integrated Hydrogen/Oxygen Technology Applied to Auxiliary Propulsion Systems," NASA CR-185289, 1990.

18. Blubaugh, A.L. and Schoenman, L., "Extended Temperature Range ACPS Thruster Investigation," NASA CR-134655, 1974.

19. Gregory, J.W. and Herr, P.N, "Hydrogen-Oxygen Space Shuttle ACPS Thruster Technology Review," AIAA Paper 72-1158, Nov. 1972. (Also, NASA TM X-68146).

20. Paster, P.D., "Hydrogen-Oxygen APS Engines," Vol. I., R-8837-33-Vol-1, Rockwell International Corp., NASA CR-120805, Feb. 1972.

21. Schoenman, L., "Hydrogen-Oxygen Auxiliary Propulsion for the Space Shuttle, Vol. I., High-Pressure Thrusters," NASA CR-120895, 1972. 
22. Johnson, R.J., Heckert, B., and Burge, H.L., "Hydrogen-Oxygen Catalytic Ignition and Thruster Investigation, Vol. II, High Pressure Thurster Evaluations," TRW-14549-6001-RO-00-Vol-2, TRW Systems Group, NASA CR-120870, Jan. 1972.

23. Senneff, J.M., "High Pressure Reverse Flow APS Engine," Bell-8636-95004, Bell Aerospace Co., NASA CR-120881, Nov. 1972.

24. Gordon, L.H., "6670-Newton Attitude-Control Thruster Using Hydrogen-Oxygen Propellant," NASA TM X-3523, 1977.

25. Richter, P.G. and Price, H.G., "Proven, Long-Life Hydrogen/Oxygen Thrust Chambers for Space Station Propulsion," NASA TM-88822, 1986.

26. Robinson, P.J. and Rosenthal, S.E., “A Proven, 25-lbf $\mathrm{H}_{2} / \mathrm{O}_{2}$ Thruster for Space Station Auxiliary Propulsion," AIAA Paper 86-1560, June 1986.

27. Robinson, P.J., "Space Station Auxiliary Thrust Chamber Technology," RPT-2210-90-FR, Aerojet General Corp., NASA CR-185296, July 1990.

28. Reed, B.D., Penko, P.F., Schneider, S.J., and Kim, S., "Experimental and Analytical Comparison of Flowfields in a $110 \mathrm{~N}$ (25 lbf) $\mathrm{H}_{2} / \mathrm{O}_{2}$ Rocket," AIAA Paper 91-2283, June 1991.

29. Iacabucci, R.S., Evans, S., Briley, G., Deleventhal, R.A., and Braunscheidel, E., "Space Station Technology Summary," 1989 JANNAF Propulsion Meeting, Vol. I, D.S. Eggleston and K.L. Strange, eds., CPIA-PUBL-515, Chemical Propulsion Information Agency, Laurel, MD, 1989, pp. 457-470.

30. Briley, G.L. and Iacabucci, R.S., "Space Station Hydrogen/Oxygen Technology," RI/RD88-256, Rockwell International Corp., NASA CR-182280, Nov. 1988.

31. Seasholtz, R.G., Zupanc, F.J., and Schneider, S.J., "Spectrally Resolved Rayleigh Scattering Diagnostic for Hydrogen-Oxygen Rocket Plume Studies," AIAA Paper 91-0462, Jan. 1991.

32. Rollbuhler, R.J., "Experimental Performance of a Water-Electrolysis Rocket," NASA TM X-1737, 1968.
33. Stechman, R.C. and Campbell, J.G., "Water Electrolysis Satellite Propulsion System," AFRPL-TR-72-132, Jan. 1973. (Avail. NTIS, AD-755384).

34. Campbell, J.G. and Stechman, R.C., "Water Electrolysis Propulsion System Testing," AFRPL-TR-74-72, Nov, 1974. (Avail. NTIS, AD-A004886).

35. Bjorklund, R.A. and Appel, M.A., "Very Low Thrust and Low Chamber Pressure $\mathrm{GO}_{2} / \mathrm{GH}_{2}$ Thruster Technology," 1984 JANNAF Propulsion Meeting, Vol. I, K.L. Strange, ed., CPIA-PUBL-390, Chemical Propulsion Information Agency, Laurel, MD, 1984, pp. 29-38.

36. Appel, M.A., Schoenman, L., and Berkman, D.K., "Oxygen/Hydrogen Thrusters for the Space Station Auxiliary Propulsion Systems," 1984 JANNAF Propulsion Meeting, Vol. I, K.L. Strange, ed., CPIA-PUBL-390, Chemical Propulsion Information Agency, Laurel, MD, 1984, pp. 339-350.

37. Armstrong, E.S., "Ignition Systems for Liquid Oxygen (LOX)/Hydrocarbon Booster Engines," 1989 JANNAF Propulsion Meeting, Vol. III, D.S. Eggleston and K.L. Strange, eds., CPIA-PUBL-515, Chemical Propulsion Information Agency, Laurel, MD, 1989,pp. 381-405. (Also, NASA TM-102033).

38. Rosenberg, S.D., Aiken, A.J., Jassowski, D.M., and Royer, K.F., "Ignition Systems for Space Shuttle Auxiliary Propulsion System," ALRC-1678-26-F, Aerojet Liquid Rocket Co., NASA CR-72890, 1972.

39. Lauffer, J.R., "Space Shuttle Auxiliary Propulsion (APS) Ignition System," R-8724, Rockwell International Corp., NASA CR-72972, May 1972.

40. Johnson, R.J., "Investigation of Thrusters for Cryogenic Reaction Control Systems," Vol. I., TRW-09849-6001-R0-00-Vol-1, TRW Systems Group, NASA CR-72784, Nov. 1970.

41. Johnson, R.J., "Investigation of Thrusters for Cryogenic Reaction Control Systems," Vol. II, TRW09849-6001-R0-00-Vol-2, TRW Systems Group, NASA CR-72785, Nov. 1970. 
42. Johnson, R.J., Heckert, B., and Burge, H.L., "Hydrogen-Oxygen Catalytic Ignition and Thruster Investigation," Vol. I. TRW-14549-6001-R0-00-Vol1, TRW Systems Group, NASA CR-120869, Nov. 1972.

43. Conrad, E.W. and Pavli, A.J., "A Resonance-Tube Igniter for Hydrogen-Oxygen Rocket Engines," NASA TM X-1460, 1967.

44. Phillips, B.R. and Pavli, A.J., "Resonance Tube Ignition of Hydrogen-Oxygen Mixtures," NASA TN D-6354, 1971.

45. Bjorklund, R.A., "Very Low Thrust Gaseous Oxygen-Hydrogen Rocket Engine Ignition Technology," 20th JANNAF Combustion Meeting, Vol. I, D.S. Eggleston, ed., CPIA-PUBL-383, Chemical Propulsion Information Agency, Laurel, MD, 1983, pp. 699-711.

46. Wooten, J.R. and Lansaw, P.T., "High Temperature Oxidation-Resistant Thruster Research," NASA CR-185233, 1990.

47. Harding, J.T., Kazaroff, J.M., and Appel, M.A., "Iridium-Coated Rhenium Thrusters by CVD," NASA TM-101309, 1988.

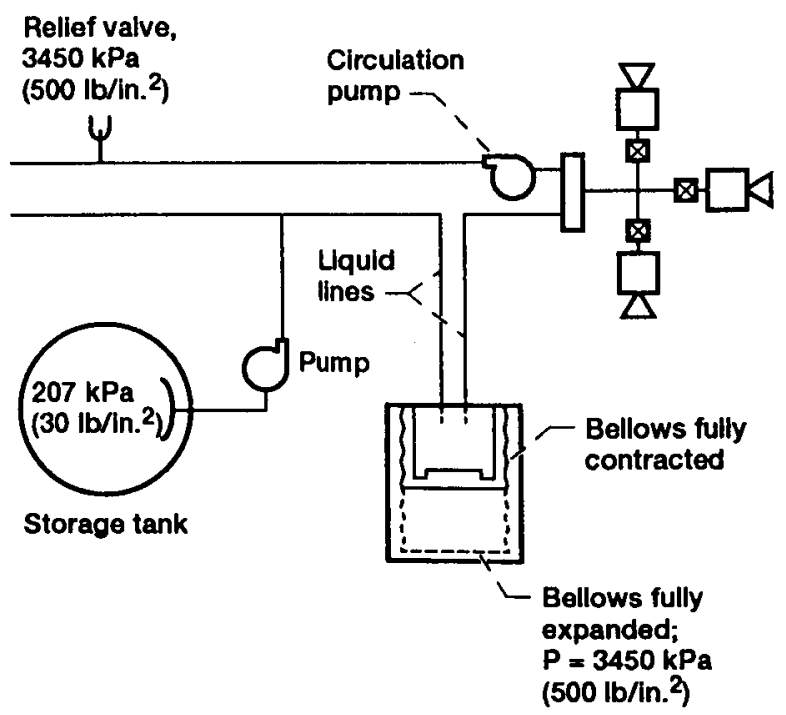

Flg. 1. Cryogenic H/O APS distribution system for Space Shuttle ${ }^{5}$. One propellant system shown; other propellant system similar.
48. Wooten, J.R. and Lansaw, P.T., "The Enabling Technology for Long-Life, High Performance On-Orbit and Orbit-Transfer Propulsion Systems: High Temperature, Oxidation Resistant Thrust Chambers," 1989 JANNAF Propulsion Meeting, Vol. I, D.S. Eggleston and K.L. Strange, eds., CPIAPUBL-515, Chemical Propulsion Information Agency, Laurel, MD, 1989, pp. 437-443.

49. Appel, M.A., et al.: "Feasibility Demonstration of a 445 N High-Performance Rocket Engine," 1989 JANNAF Propulsion Meeting, Vol. I, D.S. Eggleston and K.L. Strange, eds., CPIA-PUBL-515, Chemical Propulsion Information Agency, Laurel, MD, 1989, pp. 445-455.

50. Rosenberg, S.D. and Schoenman, L., "A New Generation of High Performance Engines for Spacecraft Propulsion," AIAA Paper 91-2039. June 1991.

51. Krohn, D.D., "Space Shuttle Vernier Thruster Long-Life Chamber Development," AIAA Paper 90-2744, July 1990.

52. Mathieu, A.C., Monteuuis, B., and Gounot, V., "Ceramic Matrix Composite Materials for a Low Thrust Bipropellant Rocket Engine," AIAA Paper 90-2054, July 1990.

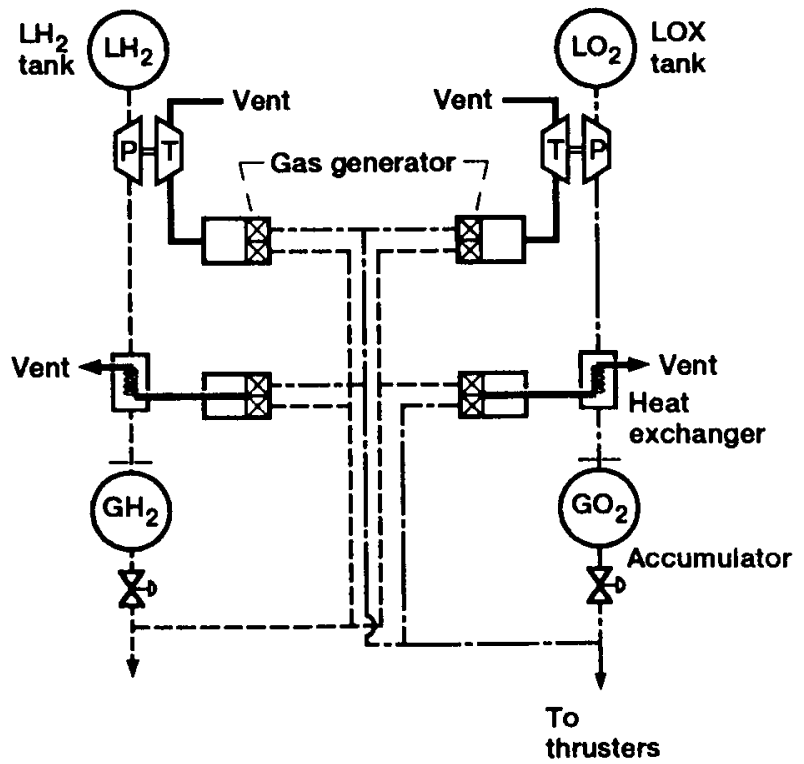

Fig. 2. High pressure gaseous H/O APS for Space Shuttle ${ }^{19}$. 


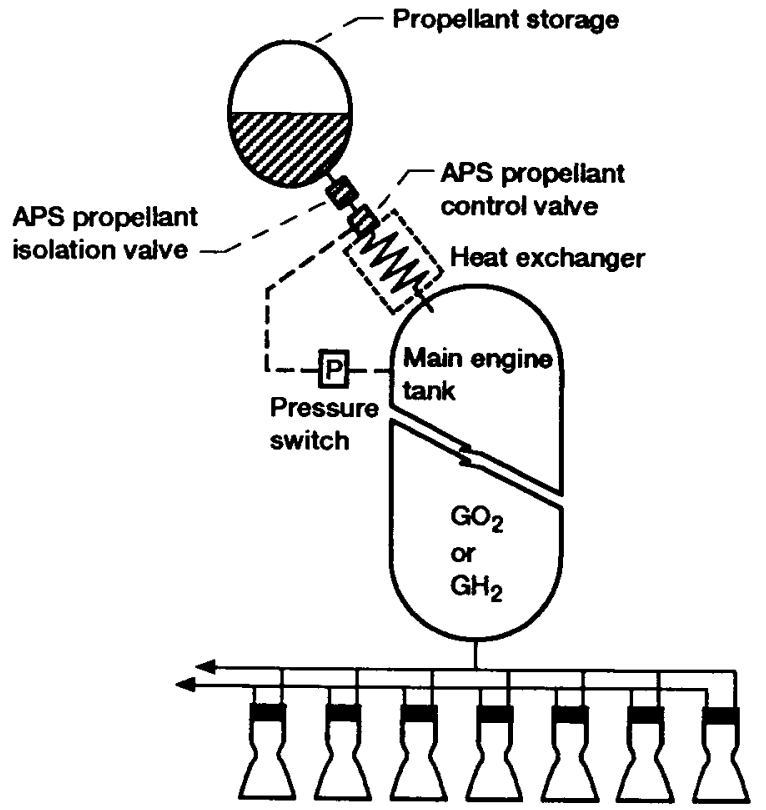

Fig. 3. Low pressure gaseous HO APS for Space Shuttle?.

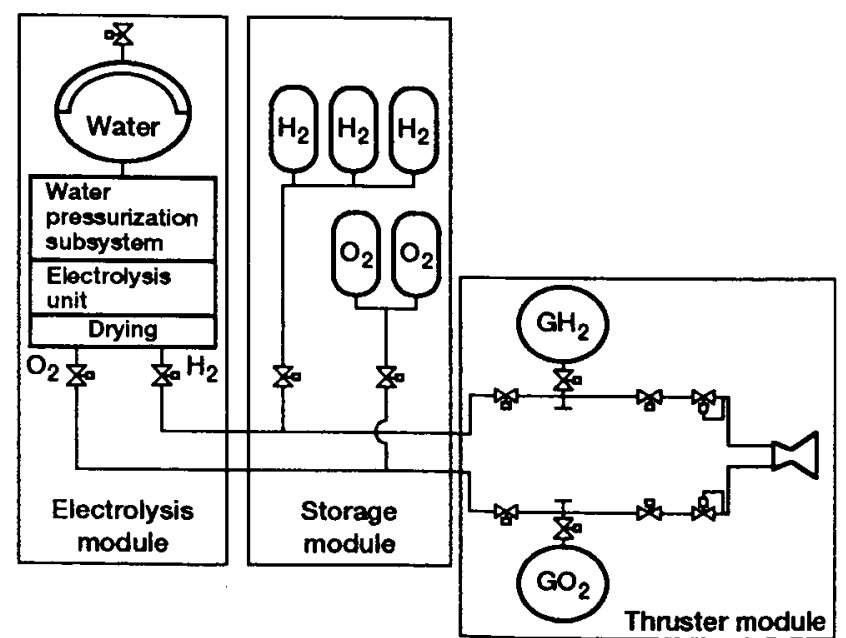

Fig. 5. Water electrolysis propulsion for Space Station Freedom 29.

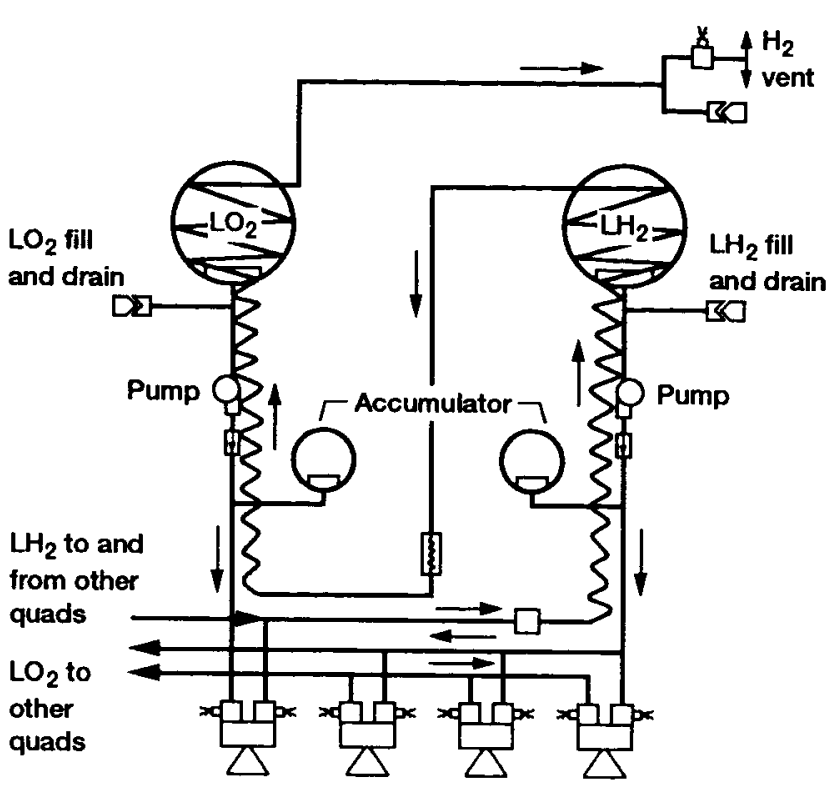

Fig. 4. Liquid HO APS for Space Tug ${ }^{11 .}$

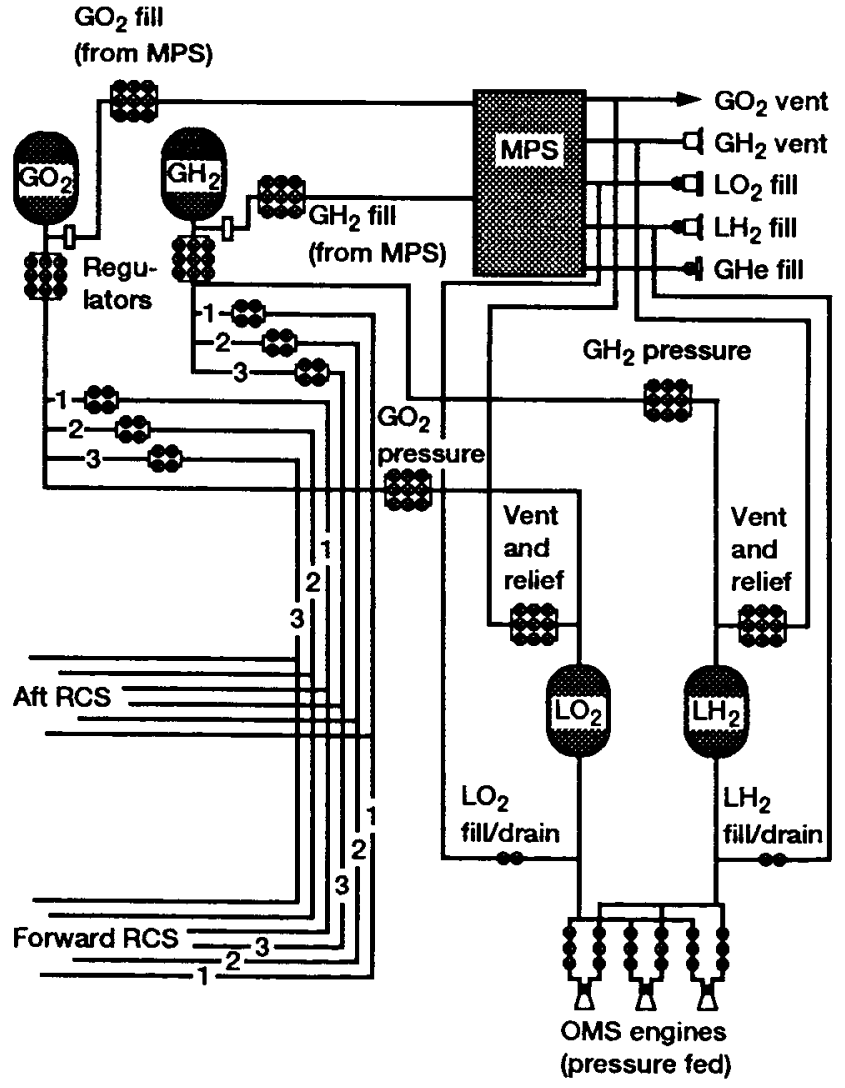

Fig. 6. Gaseous H/O RCS, liquid HO OMS for AMLS vehicle17. 


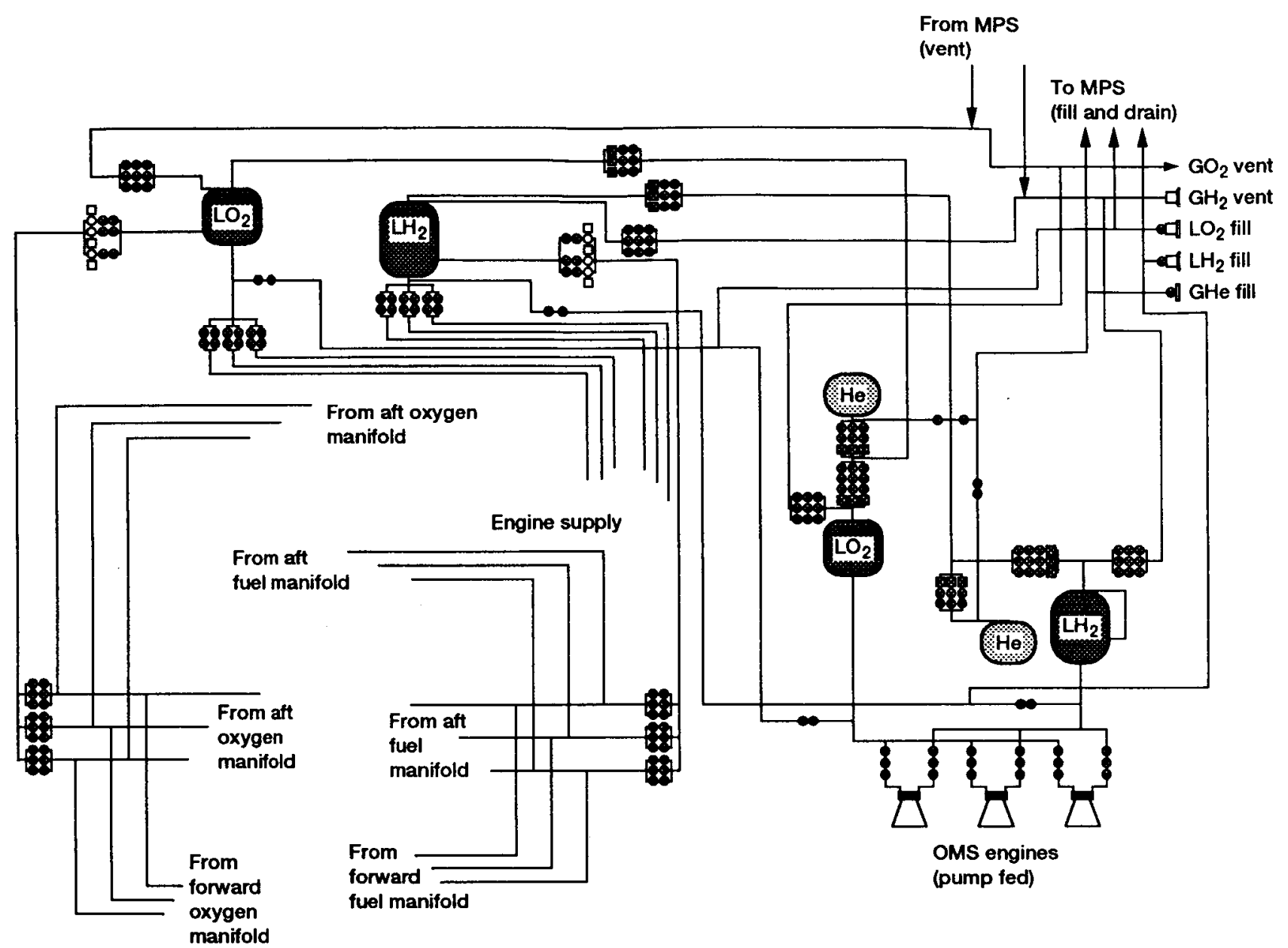

Fig. 7. Liquid HOO APS for AMLS vehicle ${ }^{17 .}$

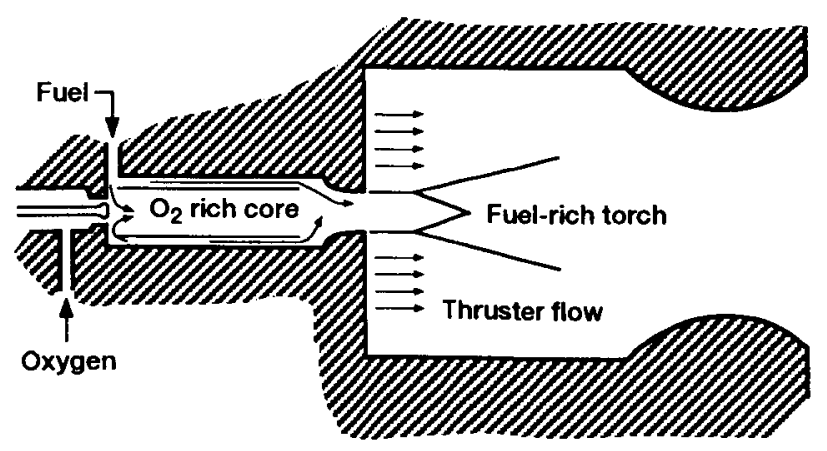

Fig. 8. Spark torch igniter 27.

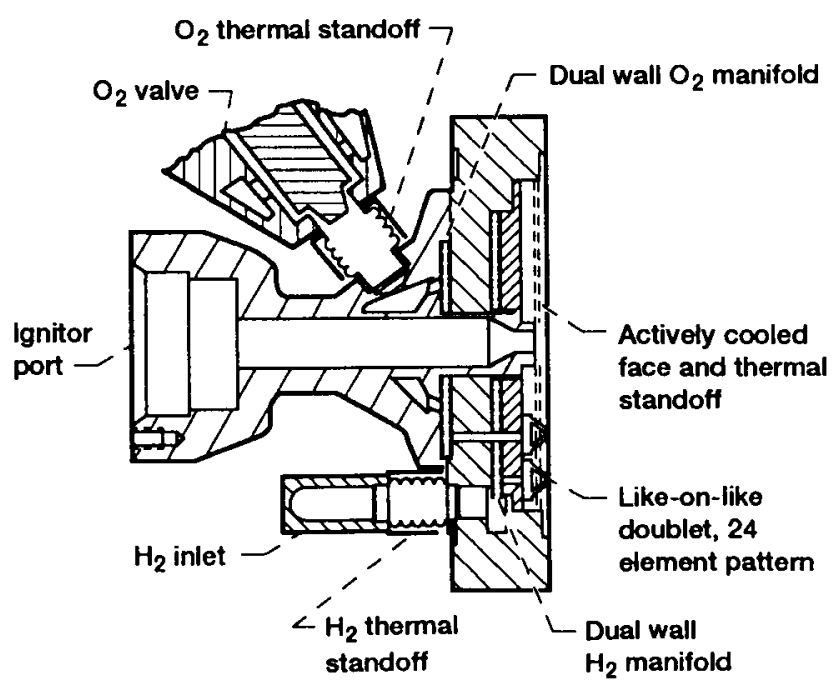

Fig. 9. Thermal management for $5500-\mathrm{N}(1250-\mathrm{lb})$, liquid H/O injector ${ }^{18}$. 


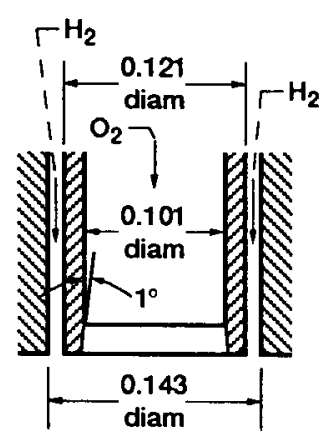

Coaxial

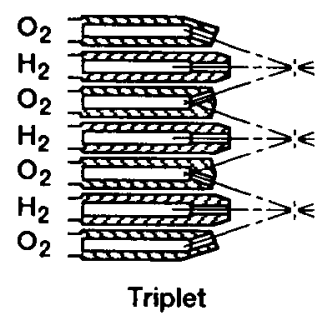

Oxidizer tube 7
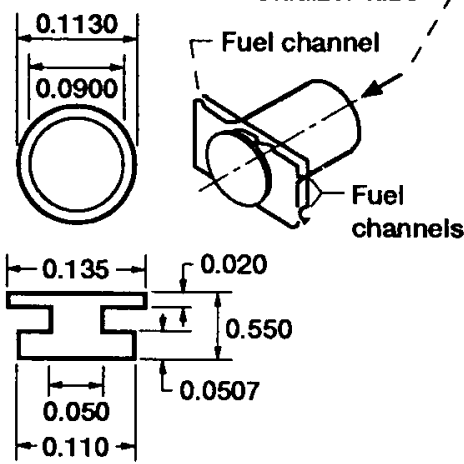

Premix
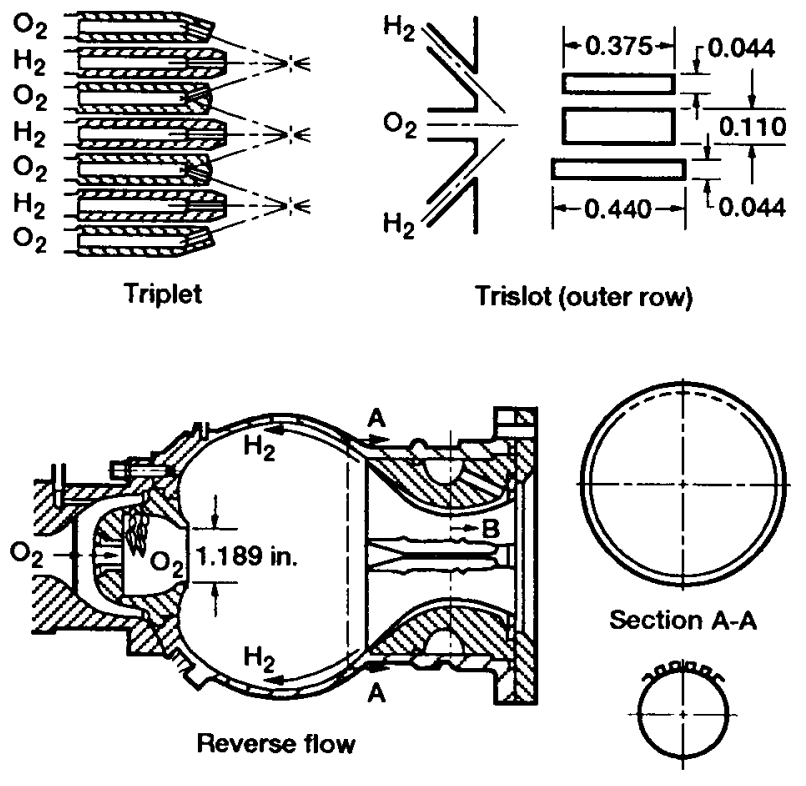

Section B-B

Fig. 10. Dual sleeve, triaxial injection concept for 110-N (25-lbf), liquid HO injector 11 .

Fig. 11. Injector concepts for 6600-N (1500-lbf), gaseous H/O thrusters ${ }^{19}$. (Dimensions are in inches.) 


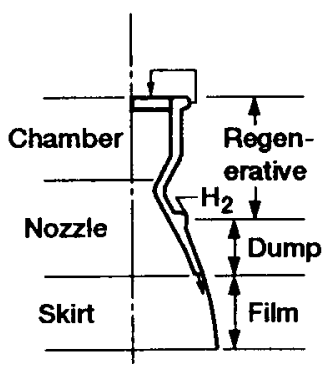

Regenerative and dump

Film and regenerative

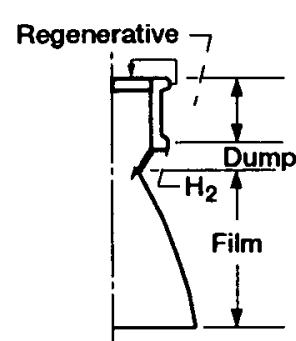

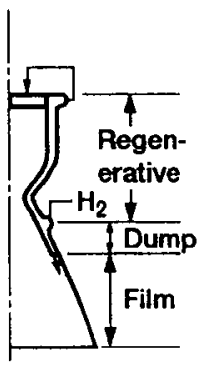

Regenerative and film

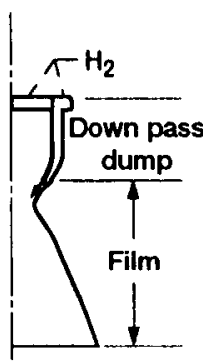

Film and dump

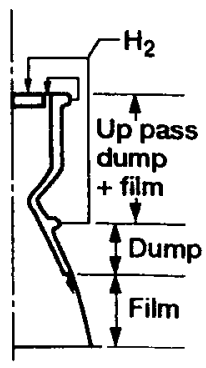

Dump and film

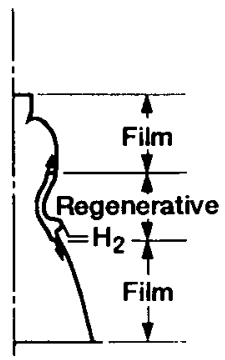

Reverse flow (regenerative and film)
Fig. 12. Thrust chamber cooling concepts for $6600-\mathrm{N}(1500-\mathrm{lb})$, gaseous H/O thrusters ${ }^{19}$.

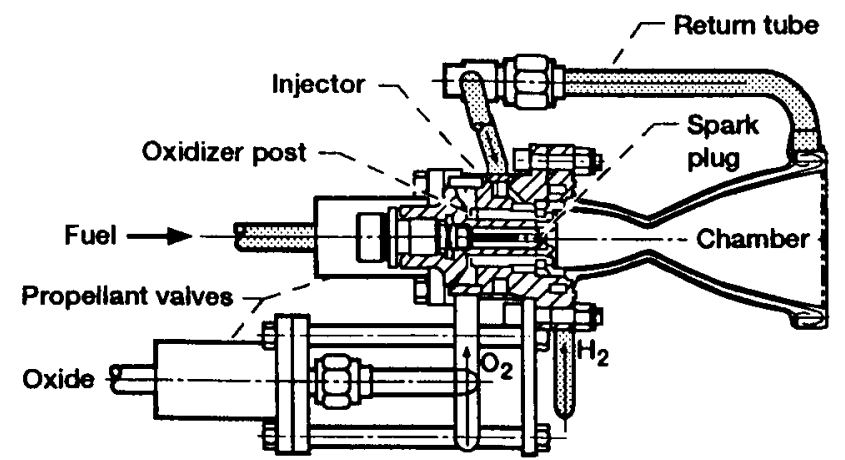

Fig. 14. Rocketclyne 110-N (25-lbf) space station thruster 29.

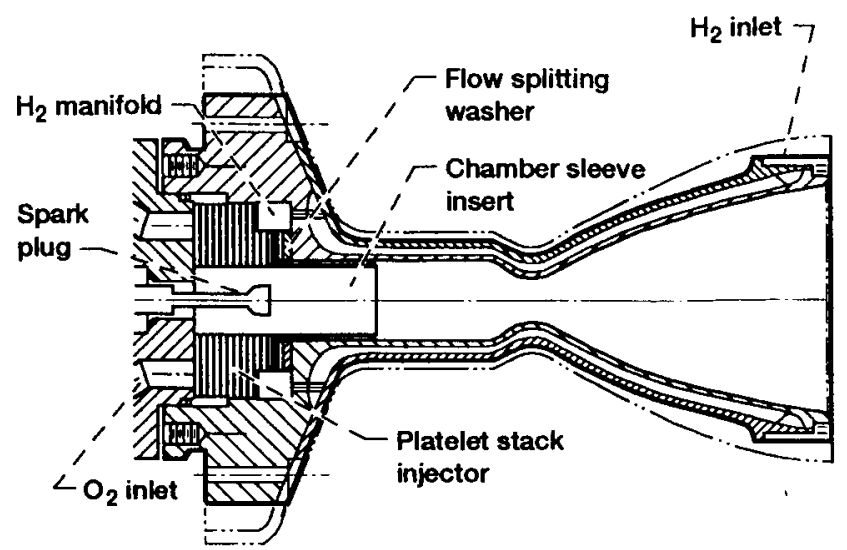

Fig. 13. Aerojet 110-N (25-lbf) space station thruster 27 .

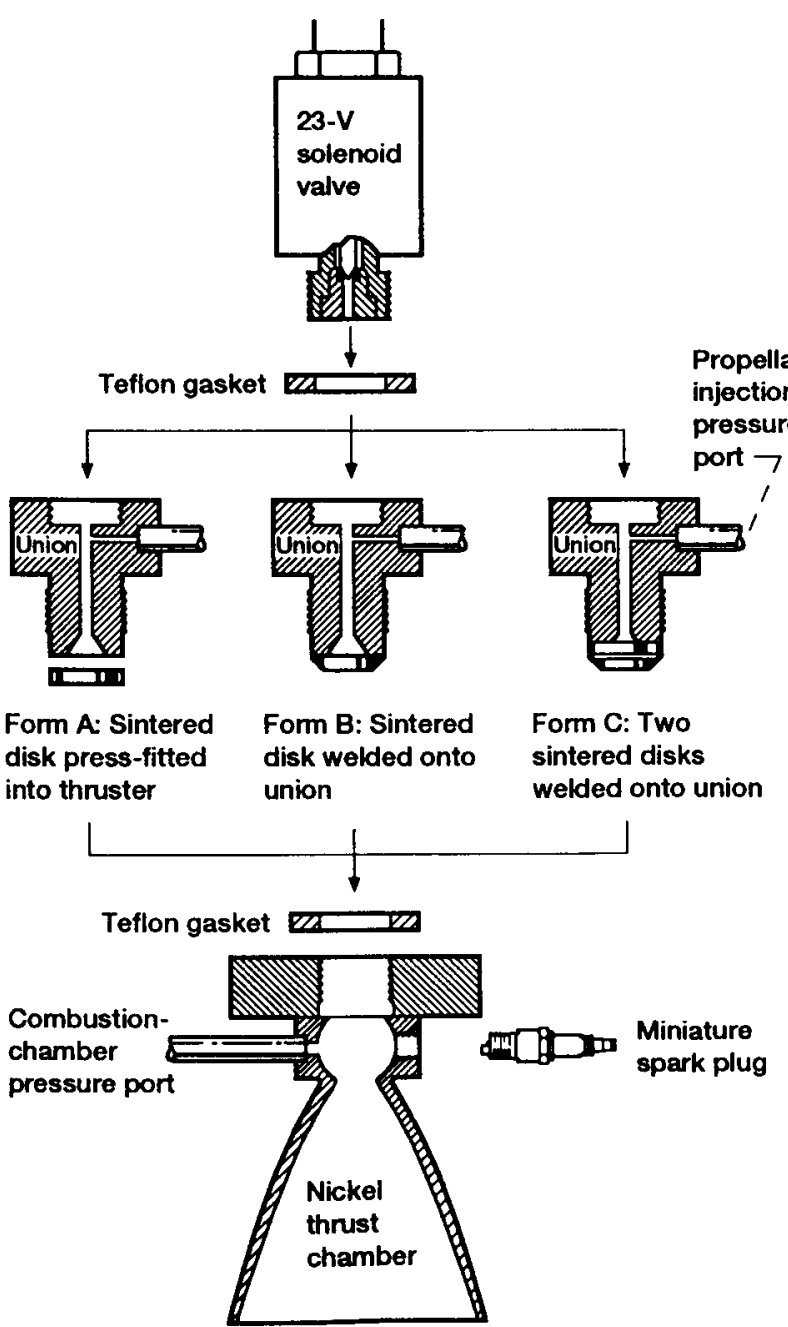

Fig. 15. 4.4-N (1-lbf) Gaseous $\mathrm{H} / \mathrm{O}$ thruster for water electrolysis propulsion system 29 . 


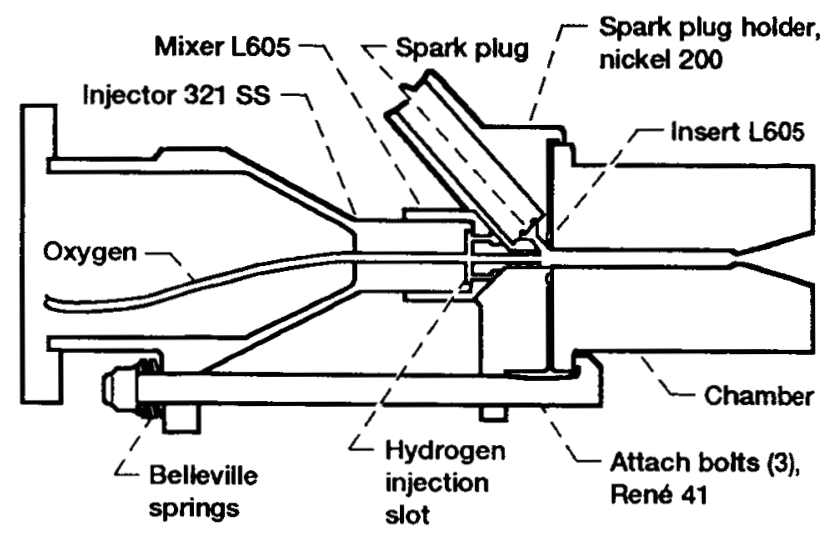

Fig. 16. Marquardt $440-\mathrm{mN}$ (0.1-lbf), gaseous H/O thruster for water electrolysis propulsion system ${ }^{34}$.

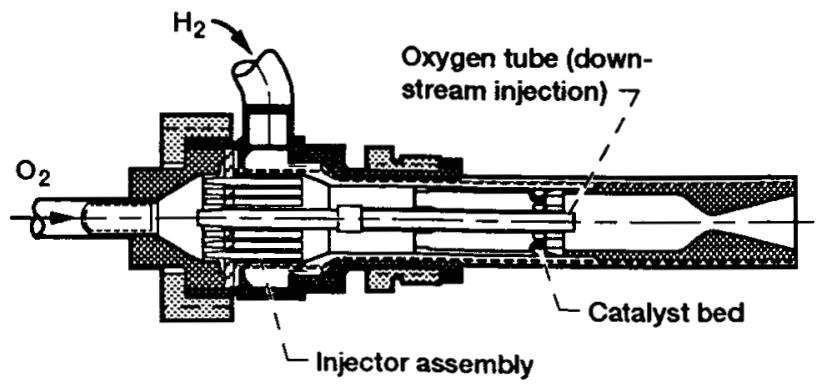

Fig. 18. Catalytic igniter with downstream injection 19 .

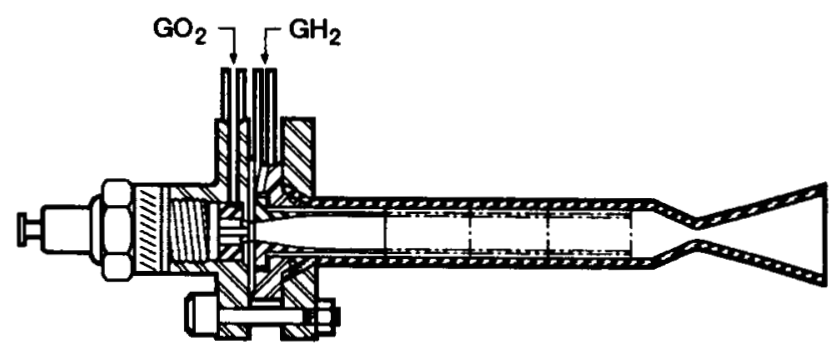

Fig. 17. JPL 2.2-N (0.5-lbf), menium thruster ${ }^{35}$.

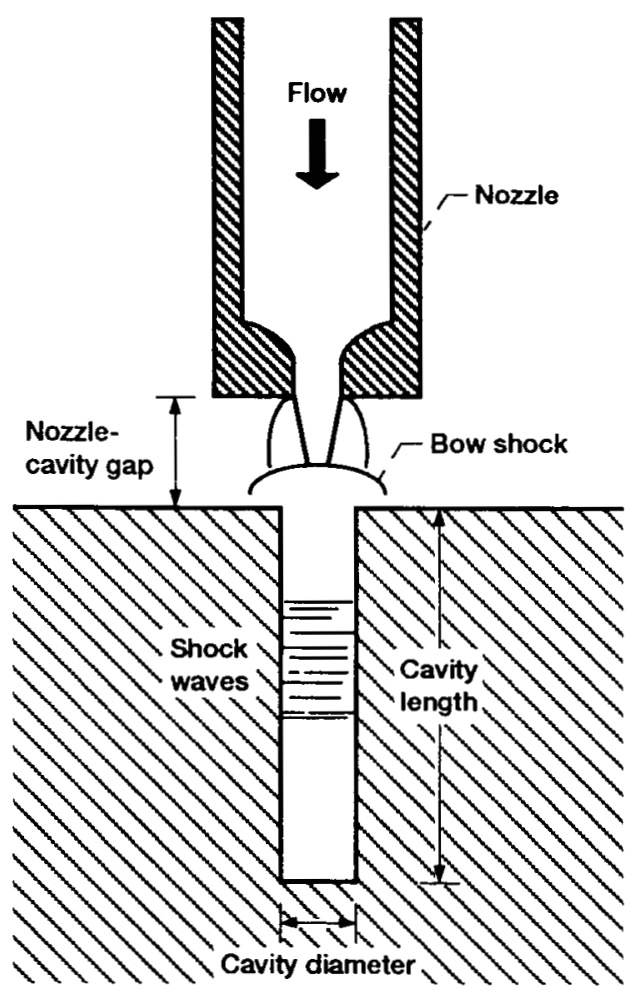

Fig. 19. Resonance ignition concept 44 . 
Public reporting burden for this collection of information is estimated to average 1 hour per response, including the time for reviewing instructions, searching existing data sources, gathering and maintaining the data needed, and completing and reviewing the collection of information. Send comments regarding this burden estimale or any other aspect of this collection of information, including suggestions for reducing this burden, to Washington Headquarters Services, Directorate for information Operations and Reports, 1215 Jefferson Davis Highway, Suite 1204, Artington, VA 22202-4302, and to the Office of Management and Budget, Paperwork Reduction Project (0704-0188), Washington, DC 20503.

\begin{tabular}{l|l|l} 
1. AGENCY USE ONLY (Leave blank) & 2. REPORT DATE & 3. REPORT TYPE AND DATES COVERED
\end{tabular}

1991

Technical Memorandum

4. TITLE AND SUBTITLE

Hydrogen/Oxygen Auxiliary Propulsion Technology

6. AUTHOR(S)

Brian D. Reed and Steven J. Schneider

7. PERFORMING ORGANIZATION NAME(S) AND ADDRESS(ES)

National Aeronautics and Space Administration

Lewis Research Center

Cleveland, Ohio 44135-3191

9. SPONSORING/MONITORING AGENCY NAMES(S) AND ADDRESS(ES)

National Aeronautics and Space Administration

Washington, D.C. 20546-0001
WU-506-42-31

8. PERForming organization

REPORT NUMBER

E-6578

\section{SUPPLEMENTARY NOTES}

Prepared for the Conference on Advanced Space Exploration Initiative Technologies cosponsored by AIAA, NASA, and OAI, Cleveland, Ohio, September 4-6, 1991. Responsible person, Brian D. Reed, (216) 433-8111.

12a. DISTRIBUTION/AVAILABILITY STATEMENT

Unclassified - Unlimited

Subject Category 20 12b. DISTRIBUTION CODE

\section{ABSTRACT (Maximum 200 words)}

This paper provides a survey of hydrogen/oxygen (H/O) auxiliary propulsion system (APS) concepts and low thrust H/O rocket technology. A review of H/O APS studies performed for the Space Shuttle, Space Tug, Space Station Freedom, and Advanced Manned Launch System programs is given. The survey also includes a review of low thrust $\mathrm{H} / \mathrm{O}$ rocket technology programs, covering liquid H/O and gaseous $\mathrm{H} / \mathrm{O}$ thrusters, ranging from $6600 \mathrm{~N}$ (1500 lbf) to $440 \mathrm{mN}(0.1 \mathrm{lbf})$ thrust. Ignition concepts for $\mathrm{H} / \mathrm{O}$ thrusters and high-temperature, oxidation-resistant chamber materials are also reviewed.

Hydrogen; Oxygen; Propulsion; Auxiliary propulsion system; Reaction control system; Integrated $\mathrm{H} / \mathrm{O}$; Space transfer vehicle; $\mathrm{H} / \mathrm{O}$ thrusters

17. SECURITY CLASSIFICATION OF REPORT Unclassified
18. SECURITY CLASSIFICATION OF THIS PAGE Unclassified
19. SECURITY CLASSIFICATION OF ABSTRACT Unclassified 